\title{
Membrane System for Recovery of Volatile Organic Compounds from Remediation Off-Gases
}

\section{Final Report}

Reporting Period Start Date: September 9, 1996

Reporting Period Start Date: September 30, 2000

Principal Author: J.G. Wijmans (P.I.)

Date Issued: August 25, 2000

Date Reissued: December 17, 2003

DOE Award Number DE-AR21-96MC33081

\author{
Submitted by \\ Membrane Technology and Research, Inc. \\ 1360 Willow Road \\ Menlo Park, CA 94025
}

Contributors to this Report:

R.W. Baker

R. Daniels

H. Hassani

R.P. Olsen

S. Goakey

X. Wang

T.R. Hofmann

R. Teixeira 


\section{DISCLAIMER}

This report was prepared as an account of work sponsored by an agency of the United States Government. Neither the United States Government nor any agency thereof, nor any of their employees, makes any warranty, express or implied, or assumes any legal liability or responsibility for the accuracy, completeness, or usefulness of any information, apparatus, product, or process disclosed, or represents that its use would not infringe privately owned rights. Reference herein to any specific commercial product, process, or service by trade name, trademark, manufacturer, or otherwise does not necessarily constitute or imply its endorsement, recommendation, or favoring by the United States Government or any agency thereof. The views and opinions of authors expressed

herein do not necessarily state or reflect those of the United States Government or any agency thereof. 


\begin{abstract}
In situ vacuum extraction, air or steam sparging, and vitrification are widely used to remediate soil contaminated with volatile organic compounds (VOCs). All of these processes produce a VOC-laden air stream from which the VOC must be removed before the air can be discharged or recycled to the generating process. Treatment of these off-gases is often a major portion of the cost of the remediation project. Currently, carbon adsorption and catalytic incineration are the most common methods of treating these gas streams.
\end{abstract}

Membrane Technology and Research, Inc. (MTR) proposed an alternative treatment technology based on selective membranes that separate the organic components from the gas stream, producing a VOC-free air stream. This technology can be applied to off-gases produced by various remediation activities and the systems can be skid-mounted and automated for easy transportation and unattended operation. The target performance for the membrane systems is to produce clean air (less than 10 ppmv VOC) for discharge or recycle, dischargeable water (less than 1 ppmw VOC), and a concentrated liquid VOC phase.

This report contains the results obtained during Phase II of a two-phase project. In Phase I, laboratory experiments were carried out to demonstrate the feasibility of the proposed approach. In the subsequent Phase II project, a demonstration system was built and operated at the McClellan Air Force Base near Sacramento, California. The membrane system was fed with off-gas from a Soil Vacuum Extraction (SVE) system.

The work performed in Phase II demonstrated that the membrane system can reduce the VOC concentration in remediation off-gas to $10 \mathrm{ppmv}$, while producing a concentrated VOC phase and dischargeable water containing less than 1 ppmw VOC. However, the tests showed that the presence of 1 to $3 \%$ carbon dioxide in the SVE off-gas reduced the treatment capacity of the system by a factor of three to four. In an economic analysis, treatment costs of the membrane system were compared with those of catalytic oxidation and carbon adsorption. This analysis showed that the treatment costs of the membrane system are higher than those of the competing technologies in the VOC concentration range up to $1 \%$. Catalytic oxidation is the most economical treatment technology for off-gases containing VOCs in the range 50 ppmv to $1 \%$, whereas carbon adsorption (off-site regeneration) is the most economical for VOC concentrations less than $50 \mathrm{ppmv}$. Because the VOC concentration in the vast majority of remediation off-gases is below $1 \%$, we conclude that the usefulness of membrane VOC-separation systems for remediation applications will be very limited. 


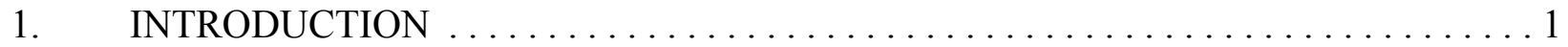

1.1 Background to Membrane Gas and Vapor Permeation $\ldots \ldots \ldots \ldots \ldots \ldots \ldots$

1.2 Technical Approach for Remediation Applications $\ldots \ldots \ldots \ldots \ldots \ldots \ldots$

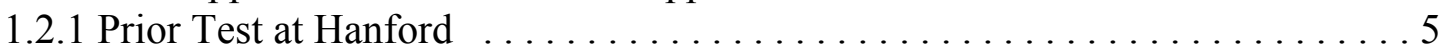

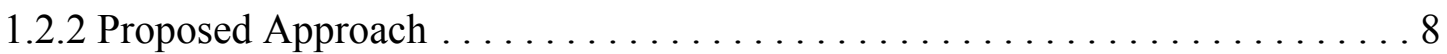

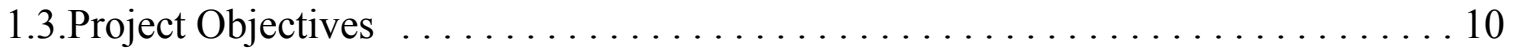

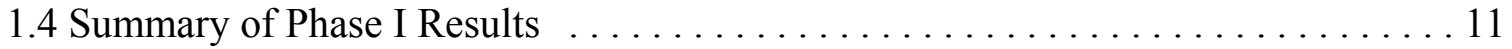

2. EXECUTIVE SUMMARY $\ldots \ldots \ldots \ldots \ldots \ldots \ldots \ldots \ldots \ldots \ldots \ldots \ldots \ldots$

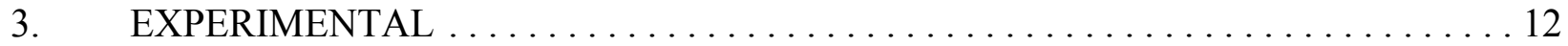

3.1 Field Demonstration System Design: Vapor Separation System . . . . . . . . . . 12

3.2 Field Demonstration System Design: Water Separation System . . . . . . . . . . 13

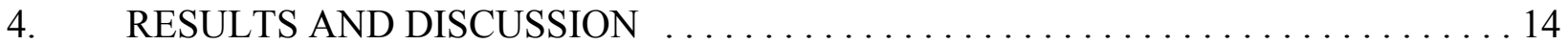

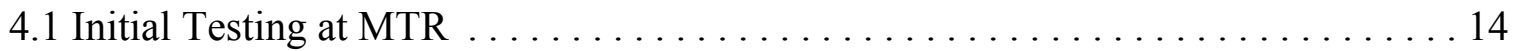

4.2 Test Site at McClellan Air Force Base $\ldots . . \ldots \ldots \ldots \ldots \ldots . \ldots \ldots \ldots$

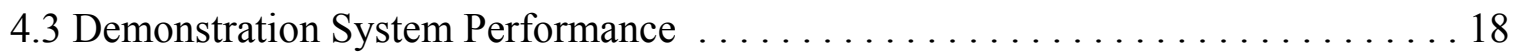

4.3.1 Effect of Carbon Dioxide Content of SVE Off-Gas on System Performance . 18

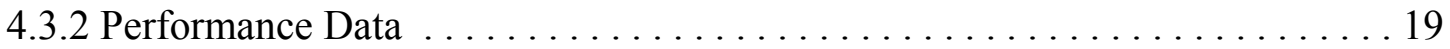

4.3.2.1 Removal of VOC from Air . . . . . . . . . . . . . . . . 19

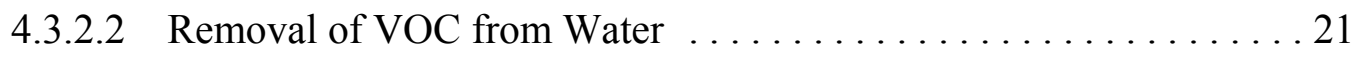

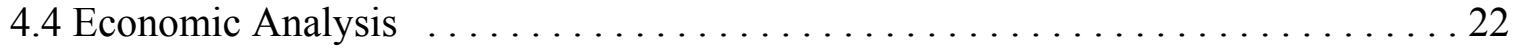

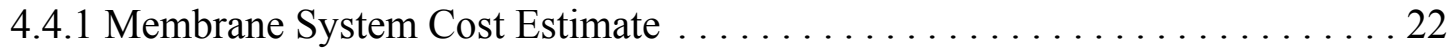

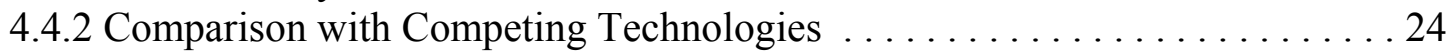

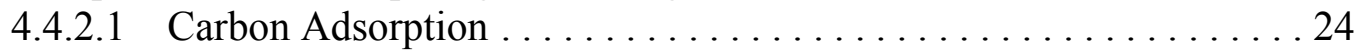

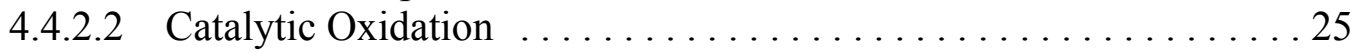

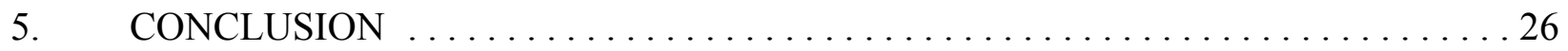

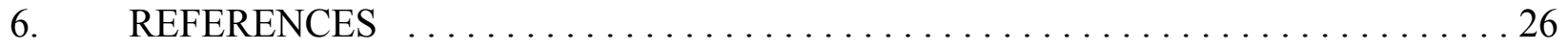

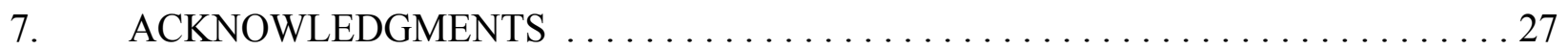

APPENDIX A: VOC Removal from Air, Data Obtained with First Set of Membrane

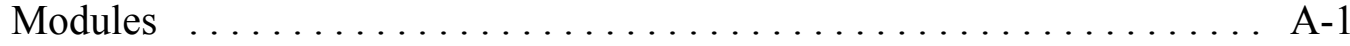

APPENDIX B: VOC Removal from Air, Data Obtained with Second Set of Membrane Modules

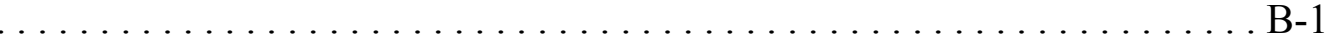

APPENDIX C: VOC Removal from Water, Data Obtained with Membrane Contactor . . . . C-1 


\section{List of Figures}

Figure 1. Schematic of an MTR composite membrane. Membrane in rolls 100-200 meters long and $10-40 \mathrm{~cm}$ wide are produced at MTR. . . . . . . . . . . . . . . 4

Figure 2. Schematic of a spiral-wound membrane module. The membrane area in MTR modules ranges from $0.3 \mathrm{~m}^{2}$ for laboratory modules to $6-15 \mathrm{~m}^{2}$ for industrial-scale modules. . 4

Figure 3. Photograph of system and performance data for carbon tetrachloride recovery by a membrane system tested at Hanford on a soil extraction vent gas stream. The 30 -scfm system provided the target $>95 \%$ VOC removal and concentrated the carbon tetrachloride into a condensed liquid that could be drummed and shipped for off-site

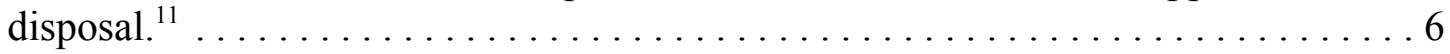

Figure 4. Flow schematic of pilot-scale membrane system tested at the Hanford Nuclear Reservation. The feed gas contained up to $1,000 \mathrm{ppm}$ carbon tetrachloride. The membrane unit separated this gas into a residue stream containing $<20 \mathrm{ppm}$ carbon tetrachloride that was vented and a permeate stream enriched in carbon tetrachloride that was remixed with the feed gas. The carbon tetrachloride builds up in this recycle loop

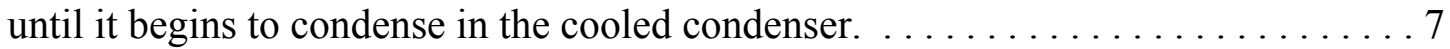

Figure 5. Schematic of membrane system for the removal of VOCs from remediation off-gases using a two-step configuration in the first membrane stage. The system produces clean air (VOC concentration 10 ppmv or less), clean water (VOC concentration 1 ppmw or less) and liquid VOC for disposal. . . . . . . . . . . . . . . . . 9

Figure 6. Schematic of the water separation system to remove VOCs from the condensate produced by the condenser in the first stage . . . . . . . . . . . . . 13

Figure 7. Methylene chloride concentration as a function of time in the buffer volume of the water separation system. The methylene chloride concentration is reduced by four orders of

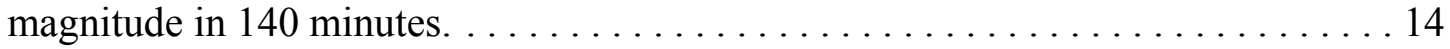

Figure 8. Diagram showing the connections between the SVE unit, the membrane demonstration system and the catalytic oxidizer at Site $\mathrm{S}$ at the National Environmental Technology Test Site, McClellan Air Force Base, Sacramento, CA. . . . . . . . . . . . . 15

Figure 9. Photograph of membrane system installed at test site. . . . . . . . . . . 16

Figure 10. Carbon dioxide concentration in SVE off-gas at McClellan Air Force Base, Site S. 18

Figure 11. VOC concentration in the membrane system inlet air (the SVE off-gas) and in the system discharge stream. Results obtained with the first set of membrane modules. . . . . 20

Figure 12. VOC concentration in the membrane system inlet air (the SVE off-gas) and in the system discharge stream. Results obtained with the second set of membrane modules. . . 21

Figure 13. VOC concentration in the water separation system inlet water (the condensate from the first stage condenser) and in the water discharge stream. . . . . . . . . 22

Figure 14. Processing costs as a function of VOC concentration in a $500-\mathrm{scfm}$ air stream for a membrane air-treatment process and for competing technologies. . . . . . 25 


\section{List of Tables}

Table 1. Characteristics of Screw and Liquid-Ring Compressors of Approximately $170 \mathrm{scfm}$

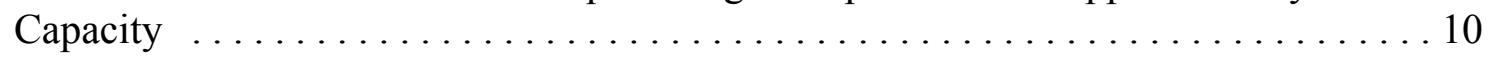

Table 2. Composition of SVE Off-Gas on September 14, 1999, Determined by EPA Method 8021

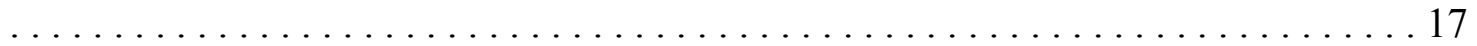

Table 3. Capital Cost Breakdown for Membrane System Treating $500 \mathrm{scfm}$ of Air Contaminated

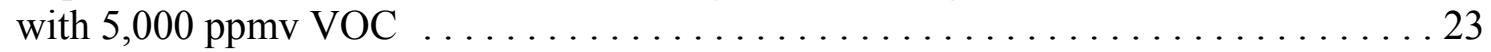

Table 4. Processing Cost Breakdown for Membrane System Treating $500 \mathrm{scfm}$ of Air Contaminated

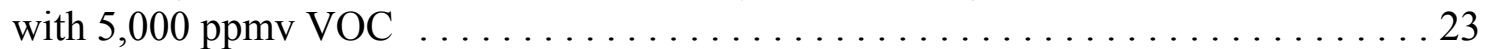

Table 5. Processing Costs as a Function of the VOC Concentration in the 500-scfm Air Stream 


\section{INTRODUCTION}

In situ vacuum extraction, air or steam sparging, and vitrification are widely used to remediate soil contaminated with volatile organic compounds (VOCs). All of these processes produce a VOC-laden air stream from which the VOC must be removed before the air can be discharged or recycled to the generating process. Treatment of these off-gases is often a major portion of the cost of the remediation project. Currently, carbon adsorption and catalytic incineration are the most common methods of treating these gas streams.

Membrane Technology and Research, Inc. (MTR) has investigated an alternative treatment technology based on selective membranes that separate the organic components from the gas stream, producing a VOC-free air stream. This technology can be applied to all of these off-gas streams and is not tied to a particular off-gas generating source. The system will be a self-contained turnkey unit, skid-mounted and completely automatic, requiring electric power but no other utilities. The system will process the off-gas, producing a concentrated liquid VOC stream and a purified gas containing less than 10 ppmv VOC that can be discharged or recycled to the gas-generating process.

Removal of VOCs from air streams with membranes is a relatively new technology. To date, most membrane systems have been installed on process streams in the refining and petrochemical industries. The first demonstration plants were installed by MTR in 1990-91, with the first commercial plants being sold in 1992-93. Currently, more than 60 MTR units are operating in the United States and overseas. The VOC concentrations in off-gases produced in DOE remediation operations are much less than those in the chemical plant streams treated by our membrane technology to date. However, a pilot test of a membrane system at the Hanford Nuclear Reservation on an off-gas stream containing 200-1,000 ppm carbon tetrachloride showed the overall feasibility of the process. The membrane system consistently achieved greater than $95 \%$ VOC removal and produced dischargeable air containing less than $20 \mathrm{ppm}$ VOC. The test also showed that modifications to the system design are required to tailor the technology to this type of remediation application. In particular, the system design must be changed to allow operation with flammable VOCs and to remove water coextracted with the VOCs, to reduce the volume of hazardous waste requiring disposal.

This report contains the results obtained during Phase II of a two-phase project. In Phase I, laboratory experiments were carried out to demonstrate the feasibility of the proposed approach. In Phase II of the project, a demonstration system was built and operated at the McClellan Air Force Base near Sacramento, California. The membrane system was fed with off-gas from a Soil Vacuum Extraction (SVE) system.

The work performed in Phase II demonstrated that the membrane system can reduce the VOC concentration in remediation off-gas to $10 \mathrm{ppmv}$, while producing a concentrated VOC phase and dischargeable water containing less than 1 ppmw VOC. However, the tests showed that the presence of 1 to $3 \%$ carbon dioxide in the SVE off-gas reduced the treatment capacity of the system by a factor of three to four. In an economic analysis, treatment costs of the membrane system were compared with those of catalytic oxidation and carbon adsorption. This analysis showed that the 
treatment costs of the membrane system are higher than those of the competing technologies in the VOC concentration range up to $1 \%$. Catalytic oxidation is the most economical treatment technology for off-gases containing VOCs in the range 50 ppmv to $1 \%$, whereas carbon adsorption (off-site regeneration) is the most economical for VOC concentrations less than 50 ppmv. Because the VOC concentration in the vast majority of remediation off-gases is below $1 \%$, we conclude that the usefulness of membrane VOC-separation systems for remediation applications will be very limited.

\subsection{Background to Membrane Gas and Vapor Permeation}

The separation of gases by selective membranes has a long history dating back to the work of Thomas Graham. However, the first systematic studies with polymer membranes of the type used today did not begin until the 1940s, when van Amerongen, Barrer and others laid the foundation of modern theories of gas permeation. ${ }^{1-3}$ Progress has been made since that time, but our basic understanding of membrane science has not changed. ${ }^{4-8}$ Although membranes with useful selectivities to commercially interesting gas mixtures were known by the 1960s, the membranes were too expensive and the permeation rates were too low for large-scale applications. Both of these problems were solved in the 1960s and early 1970s by the developers of reverse osmosis membranes, who were the first to make defect-free, high-flux asymmetric membranes and incorporate large surface areas of these membranes into modules. ${ }^{9,10}$ The technology to produce such membranes and modules is well developed at MTR.

A synthetic polymer membrane can separate the components of a gas or vapor mixture because the components permeate the membrane at different rates. The basic model of membrane transport continues to be the solution-diffusion model developed by van Amerongen, Barrer and others. ${ }^{1-3}$ In this model, it is assumed that gas at the high-pressure side of the membrane dissolves in the membrane material and diffuses down a concentration gradient to the low-pressure side of the membrane, where the gas is desorbed. It is also assumed that the gas phases on either side of the membrane are in thermodynamic equilibrium with their respective polymeric interfaces and that the interfacial sorption and desorption process is rapid compared with the rate of diffusion through the membrane. Thus, the rate-limiting step is diffusion through the polymer membrane, governed by Fick's law of diffusion. Fick's law leads to the equation

$$
J, \frac{D S \Delta p}{R}
$$

where $J$ is the membrane flux $\left[\mathrm{cm}^{3}(\mathrm{STP}) / \mathrm{cm}^{2} . \mathrm{s}\right], D$ is the diffusion coefficient of the gas in the membrane [ $\mathrm{cm}^{2}$ ब a and is a measure of the gas mobility, $S$ is the Henry's law sorption coefficient linking the concentration of the gas in the membrane material to the pressure in the adjacent gas $\left[\mathrm{cm}^{3}(\mathrm{STP}) / \mathrm{cm}^{3} \cdot \mathrm{cmHg}\right], \Delta p$ is the pressure difference across the membrane $[\mathrm{cmHg}]$, and $R$ is the membrane thickness $(\mathrm{cm})$. Equation (1) can also be written

$$
J, \frac{P \Delta p}{R}
$$


where $P$ is the permeability, equal to the product $D S$, and is a measure of the rate at which a particular gas moves through a membrane of standard thickness $(1 \mathrm{~cm})$ under a standard pressure difference $(1 \mathrm{cmHg})$. The permeability unit, $1 \times 10^{-10} \mathrm{~cm}^{3}(\mathrm{STP}) \mathrm{cm} / \mathrm{cm}^{2} \cdot \mathrm{s} \cdot \mathrm{cmHg}$, is often called a Barrer, after R.M. Barrer, a pioneer in membrane permeation studies. ${ }^{2}$

The transport of any gaseous component through a membrane is characterized by a permeation flux, $Q\left[\mathrm{~cm}^{3}(\mathrm{STP}) / \mathrm{cm}^{2}\right.$ @emHg], defined as

$$
Q^{\prime} \frac{P}{R}, \frac{J}{\Delta p}
$$

or

$$
J^{\prime} Q \Delta p
$$

A measure of the ability of a membrane to separate two gases or vapors (1) and (2) is the selectivity, $\alpha$, defined as the ratio of their permeabilities:

$$
\alpha, \frac{P_{1}}{P_{2}}, \frac{D_{1} S_{1}}{D_{2} S_{2}}
$$

or, in terms of the individual overall normalized permeation fluxes,

$$
\alpha, \frac{Q_{1}}{Q_{2}}
$$

since the membrane thickness $R$ is constant. The intrinsic selectivity of a polymer material is established by measuring the permeabilities with pure gas or vapor samples, then calculating the ratio. The selectivity obtained in an actual separation process is determined by making permeation measurements with gas mixtures.

In glassy materials, the dominant feature in the selectivity is the ratio of the diffusion coefficients $D_{1} / D_{2}$, which is heavily dependent on the ratio of the molecular sizes. In rubbery materials, the dominant feature is the ratio of the sorption coefficients $S_{1} / S_{2}$, which reflects the ratio of the condensabilities of the two permeants. Rubbery membrane materials efficiently separate organic vapors, which have relatively large molecules but are easily condensed, from gases, which are smaller molecules but not easily condensed. MTR specializes in the separation of organic vapors from air and other gas streams and has considerable experience in the production of rubbery membranes.

The membranes developed by MTR for the separation of organic vapors from air are composite structures, as shown schematically in Figure 1. The tough, open, microporous layer provides strength and the ultrathin selective coating is responsible for the separation properties. 


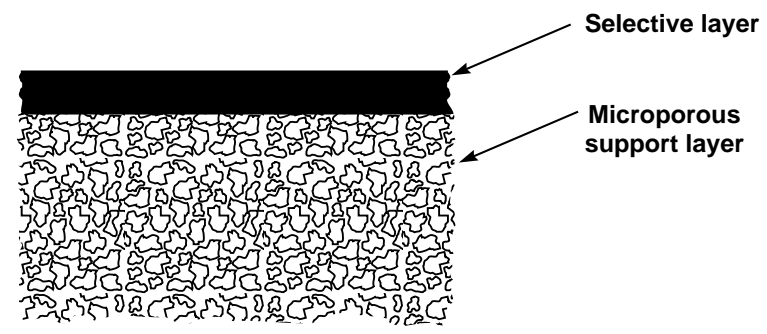

Figure 1. Schematic of an MTR composite membrane. Membrane in rolls 100-200 meters long and $10-40 \mathrm{~cm}$ wide are produced at MTR.

The composite membranes are incorporated into spiral-wound modules of the type illustrated schematically in Figure 2. Feed gas enters the module and flows between the membrane leaves. The component of the feed that is preferentially permeated by the membrane spirals inward to a central permeate collection pipe. The remainder of the feed flows across the membrane surface and exits as the residue. To meet the capacity and separation requirements of a particular application, modules are connected in serial or parallel flow arrangements.

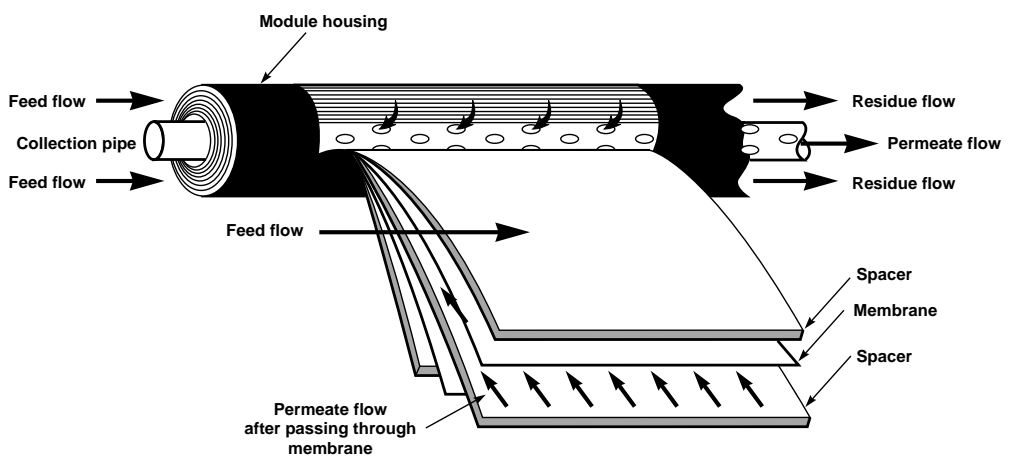

Figure 2. Schematic of a spiral-wound membrane module. The membrane area in MTR modules ranges from $0.3 \mathrm{~m}^{2}$ for laboratory modules to $6-15 \mathrm{~m}^{2}$ for industrial-scale modules.

Certain membrane materials, particularly hydrophobic rubbery polymers, possess an intrinsically high selectivity for organic vapors over air, allowing useful separations to be performed. Our experience has shown that a membrane selectivity of greater than 10 is required if a membrane process is to be economically viable for the recovery of most industrial solvents. However, if the compound to be recovered is significantly more expensive than common industrial solvents, a membrane selectivity between 5 and 10 would be sufficient. Most solvents have a membrane selectivity in excess of 10 . 


\subsection{Technical Approach for Remediation Applications}

\subsubsection{Prior Test at Hanford}

Off-gases produced in DOE remediation operations are much less concentrated in VOCs than the chemical plant streams treated by our membrane technology to date. However, we performed a successful pilot test of a membrane system on this type of gas stream at the Hanford Nuclear Reservation in conjunction with Westinghouse Corporation. ${ }^{11,12}$ The target off-gas was air containing carbon tetrachloride produced by in-situ vacuum extraction of contaminated soil. The gas was saturated with water and contained $200-1,000 \mathrm{ppm}$ carbon tetrachloride. The membrane system consistently achieved greater than $95 \%$ VOC removal, producing dischargeable air containing less than $20 \mathrm{ppm}$ VOC. A photograph of the unit ready for shipping to the site, together with a performance curve obtained during the test are shown in Figure 3. 

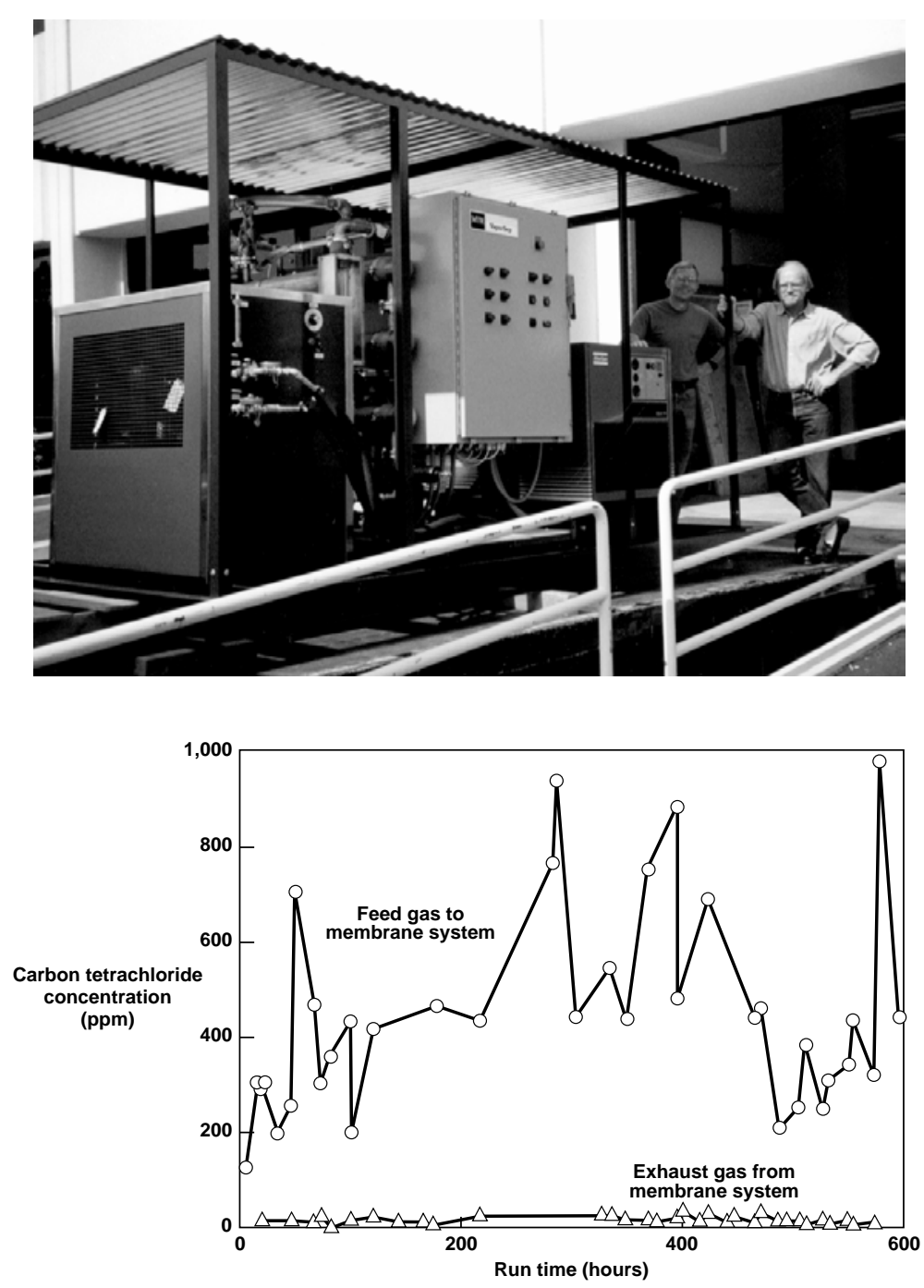

Figure 3. Photograph of system and performance data for carbon tetrachloride recovery by a membrane system tested at Hanford on a soil extraction vent gas stream. The 30 -scfm system provided the target $>95 \%$ VOC removal and concentrated the carbon tetrachloride into a condensed liquid that could be drummed and shipped for off-site disposal. ${ }^{11}$

The design of the membrane system used at Hanford is shown in Figure 4. The VOC-laden feed air is compressed to $150 \mathrm{psia}$. On cooling, a portion of the VOC condenses; the remaining gas then contacts one side of a membrane that is permeable to organic vapors but relatively permeable to air. A purified air stream is removed as the residue gas; the VOC-enriched permeate is returned to the front end of the compressor for recycling through the unit. 


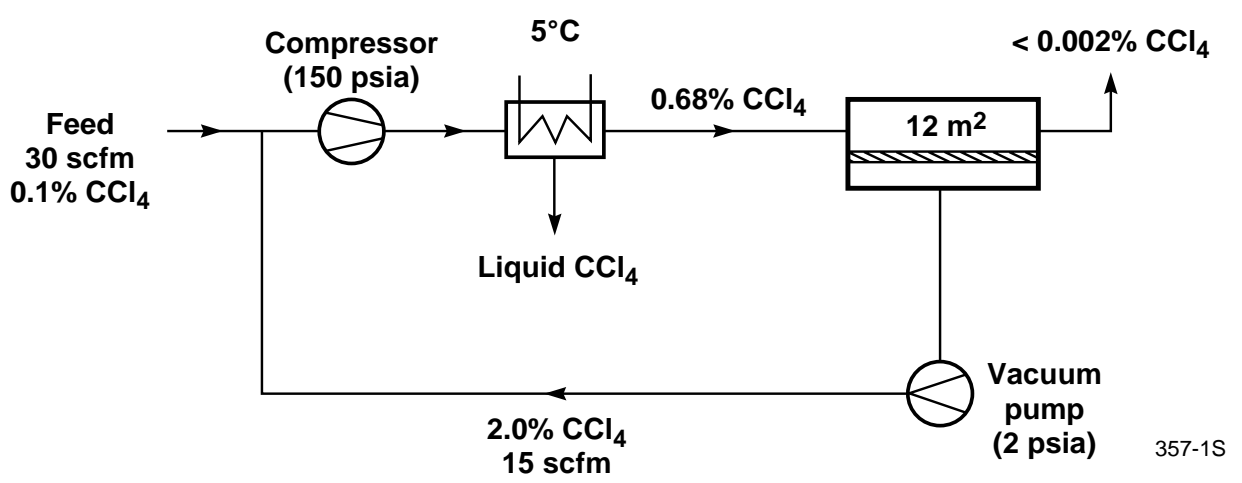

Figure 4. Flow schematic of pilot-scale membrane system tested at the Hanford Nuclear Reservation. The feed gas contained up to $1,000 \mathrm{ppm}$ carbon tetrachloride. The membrane unit separated this gas into a residue stream containing $<20 \mathrm{ppm}$ carbon tetrachloride that was vented and a permeate stream enriched in carbon tetrachloride that was remixed with the feed gas. The carbon tetrachloride builds up in this recycle loop until it begins to condense in the cooled condenser.

The Hanford pilot test demonstrated the overall feasibility of applying membrane vapor separation to VOC-laden off-gas from soil remediation, but raised a number of issues. The objective of the project described here was to address the following issues:

(1) The off-gas treated by the unit was saturated with water vapor and contained approximately 10-20 times as much water vapor as VOC. Because the system removed both water vapor and organic vapors, the condensed VOC liquid was heavily contaminated with water. The membrane unit design developed for this project separates the condensed water vapor from the condensed VOC, thereby reducing the volume of hazardous waste requiring disposal.

(2) The off-gas produced at many DOE sites contains flammable VOCs such as hydrocarbon fuel vapors and aromatic hydrocarbons. A widely applicable treatment technology must be able to handle off-gas containing these VOCs. The recycle design shown in Figure 4 and tested at Hanford cannot treat such streams because of the potential explosion hazard caused by flammable vapors concentrating in the membrane recycle loop. An alternative design, suitable for operation with flammable feed gas, was developed in this project.

(3) The system must be designed to meet the special needs of DOE remediation operations, including the requirements that:

- The system is rugged, operator-free, and low maintenance and requires electricity but no other utilities.

- The system is self-contained, turnkey and skid-mounted and is transportable by truck.

- The system requires minimal site preparation. 
- The system can be unloaded and assembled quickly ( less than a day) and easily (using only a fork lift and simple hand tools). Decontamination and disassembly should be just as easy.

- The system can safely handle off-gases containing a wide range of VOCs, flammable and nonflammable, chlorinated and non-chlorinated, varying in concentration from a few hundred ppmv to several thousand ppmv.

- The final off-gas discharged after treatment always contains less than 10 ppmv VOC.

\subsubsection{Proposed Approach}

A simplified schematic of the proposed system is shown in Figure 5. This design incorporated the new features suggested by our previous experience from the Hanford test and our current understanding of DOE's needs. As can be seen from Figure 5, the off-gas containing water vapor and VOCs is compressed to 190 psia in a standard air compressor. The compressor after-cooler condenses out most of the water vapor and some of the VOC content. A small air stripper removes the VOCs from the condensed water so that the water can be discharged. The air leaving the aftercooler enters two sets of membrane modules in series, each module containing a membrane that is much more permeable to VOCs than to air. Most of the VOCs and some of the air permeate the membrane in the first membrane step; this VOC-enriched permeate stream is recompressed in a liquid-ring vacuum pump. The air exhaust from the air stripper is also sent to this vacuum pump. The vacuum pump compresses the air to about 80 psia, after which the VOC content is condensed in a heat exchanger. The air leaving the heat exchanger still contains an appreciable amount of VOC, most of which is removed in a second membrane stage prior to the inlet of the system. The VOCenriched permeate is returned to the vacuum pump, thereby creating a concentration loop for the VOCs that facilitates their condensation in the heat exchanger. The VOC-depleted nonpermeated stream produced by the first membrane step is fed to the second membrane step where the remaining VOCs are removed to achieve the $10 \mathrm{ppmv}$ VOC discharge level. The permeate stream produced by the second membrane step is returned to the inlet of the compressor. 


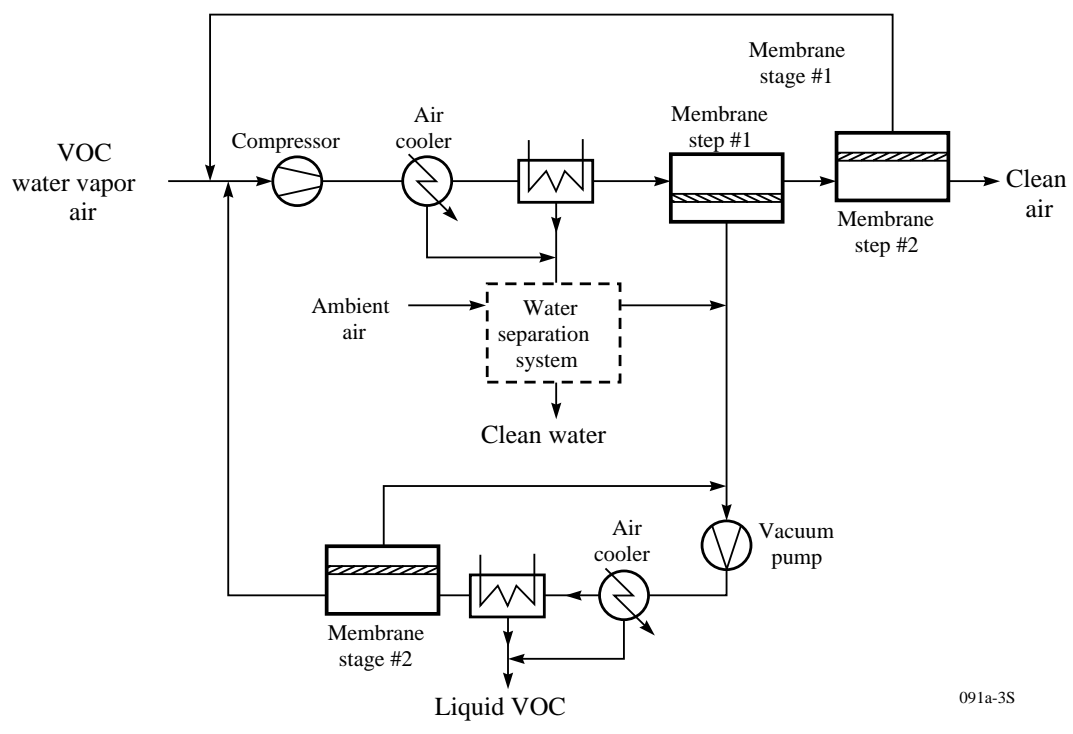

Figure 5. Schematic of membrane system for the removal of VOCs from remediation off-gases using a two-step configuration in the first membrane stage. The system produces clean air (VOC concentration $10 \mathrm{ppmv}$ or less), clean water (VOC concentration 1 ppmw or less) and liquid VOC for disposal.

To be widely used by DOE, the off-gas treatment process must be able to treat a wide variety of organic vapor mixtures, both flammable and nonflammable, in the concentration range $0-2 \mathrm{vol} \%$. The need to process flammable gas mixtures impacts the choice of the main compressor, the most expensive and important piece of rotating equipment in a membrane vapor separation system. The Hanford pilot trial demonstrated that a low-cost screw compressor could be used with vapor mixtures in the target range. However, a screw compressor cannot be used with flammable vapor mixtures in a system of the Hanford design because organic vapors build up in the recirculation loop. As shown in Figure 4, the vapor concentration in the recirculation loop can easily be 5-10 times the vapor concentration in the incoming feed gas. Normally, this high concentration of feed vapor would be compressed by a liquid-ring compressor. Liquid-ring compressors are rugged, reliable, and intrinsically safe even when operated with flammable organic vapor mixtures, but they are three to five times more expensive than screw compressors of the same capacity. Also, because they are less efficient, liquid-ring compressors use more than twice as much power as screw compressors. This excess power is lost as waste heat; consequently, liquid-ring compressors need an external supply of cooling water, whereas screw compressors are normally air cooled. A comparison of screw and liquid-ring compressors of approximately the same capacity is given in Table 1. 
Table 1. Characteristics of Screw and Liquid-Ring Compressors of Approximately $170 \mathrm{scfm}$ Capacity.

\begin{tabular}{||l|c|c||}
\hline \multicolumn{1}{|c|}{ Characteristic } & $\begin{array}{c}\text { Screw Compressor } \\
\text { (Kaiser or Equivalent) }\end{array}$ & $\begin{array}{c}\text { Liquid-Ring Compressor } \\
\text { (Sihi or Equivalent) }\end{array}$ \\
\hline Maximum Pressure & $190 \mathrm{psia}$ & $115 \mathrm{psia}$ \\
Power Required & $50 \mathrm{hp}$ & $100 \mathrm{hp}$ \\
Cooling Method & Air & $12 \mathrm{gal} / \mathrm{min}$ water \\
\hline
\end{tabular}

As Table 1 shows, the advantages offered by a screw compressor are compelling. We have, therefore, modified the Hanford design to ensure that the main compressor always operates below $50 \%$ of the lower explosion limit (LEL) allowing a screw compressor to be used. This new design incorporates two sets of membrane modules, as shown in Figure 5. The first set of modules (the VOC removal section in Figure 5), separates the organic vapors from the feed gas, producing dischargeable air and a low-pressure permeate enriched five- to six-fold over the feed. This gas is then concentrated to the point of condensation in a secondary recycle loop (the VOC concentration and condensation section in Figure 5). Because the organic vapor concentration may enter the explosive range in this loop, a liquid-ring vacuum pump must be used. However, the volume of gas to be treated is now only $20 \%$ of the feed gas, so the size of this unit is manageable, and the cooling requirements of the vacuum pump are small enough that cooling by a built-in chiller is sufficient.

The temperature of the compressed gas leaving the main compressor stream in Figure 5 is 100$120 \mathrm{EC}$. On cooling this gas to 40-60EC in a fan-cooled after-cooler, approximately $90 \%$ of the water vapor in the original feed will condense. This liquid water may also contain a small amount of dissolved VOCs, depending on the type and concentration of the VOC in the feed. A very small air stripper can be used to remove VOC from this water. The bleed air from the stripper, which contains the VOCs removed from the water, is sent to the VOC concentration and condensation loop.

\subsection{Project Objectives}

The overall objective of the project was to demonstrate the technical and economic feasibility of using a membrane-based treatment system for off-gas from a range of remediation operations. To achieve this objective we designed, constructed, and evaluated a proof-of-concept membrane system able to treat $100 \mathrm{scfm}$ of off-gas. This unit was be tested at a field site.

The specific objectives of the project were to:

1. Develop the concept for a membrane-based VOC removal system capable of reducing the VOC content of remediation off-gases to $10 \mathrm{ppmv}$, including a water separation system capable of producing water containing less than 1 ppmw VOC.

2. Demonstrate in the laboratory the effectiveness of the water separation step. 
3. Demonstrate in the laboratory the effectiveness of baffled modules.

4. Arrange for a field test at a DOE site.

5. Construct a 100-scfm capacity demonstration system.

6. Operate the system at the site.

7. Perform a technical and economic analysis.

\subsection{Summary of Phase I Results}

Phase I of the project addressed objectives 1 through 4; a complete description of the results of the work can be found in the Phase I Topical Report. ${ }^{13}$ In summary, the work performed in Phase I demonstrated that:

(1) Membrane modules containing feed-side baffles have better VOC/air separation properties than conventional modules.

(2) Hollow-fiber contactors are very efficient stripping devices for the removal of VOC from water.

(3) The novel system design developed can reduce the VOC concentration in remediation offgas to $10 \mathrm{ppmv}$, while producing a concentrated VOC phase and dischargeable water containing less than 1 ppmw VOC.

(4) The membrane system is competitive with carbon adsorption if the VOC concentration in the remediation off-gas is 100 ppmv or higher.

A design was prepared for a demonstration system able to treat $100 \mathrm{scfm}$ off-gas. A commitment to host a field demonstration was received from the National Environmental Technology Test Site located at the McClellan Air Force Base near Sacramento, CA.

\section{EXECUTIVE SUMMARY}

In situ vacuum extraction, air or steam sparging, and vitrification are widely used to remediate soil contaminated with volatile organic compounds (VOCs). All of these processes produce a VOC-laden air stream from which the VOC must be removed before the air can be discharged or recycled to the generating process. Treatment of these off-gases is often a major portion of the cost of the remediation project. Currently, carbon adsorption and catalytic incineration are the most common methods of treating these gas streams.

Membrane Technology and Research, Inc. (MTR) proposed an alternative treatment technology based on selective membranes that separate the organic components from the gas stream, producing 
a VOC-free air stream. This technology can be applied to off-gases produced by various remediation activities and the systems can be skid-mounted and automated for easy transportation and unattended operation. The target performance for the membrane systems is to produce clean air (less than 10 ppmv VOC) for discharge or recycle, dischargeable water (less than 1 ppmw VOC), and a concentrated liquid VOC phase.

This report contains the results obtained during Phase II of a two-phase project. In Phase I, laboratory experiments were carried out to demonstrate the feasibility of the proposed approach. In the subsequent Phase II project, a demonstration system was built and operated at the McClellan Air Force Base near Sacramento, California. The membrane system was fed with off-gas from a Soil Vacuum Extraction (SVE) system.

The work performed in Phase II demonstrated that the membrane system can reduce the VOC concentration in remediation off-gas to $10 \mathrm{ppmv}$, while producing a concentrated VOC phase and dischargeable water containing less than 1 ppmw VOC. However, the tests showed that the presence of 1 to $3 \%$ carbon dioxide in the SVE off-gas reduced the treatment capacity of the system by a factor of three to four. In an economic analysis, treatment costs of the membrane system were compared with those of catalytic oxidation and carbon adsorption. This analysis showed that the treatment costs of the membrane system are higher than those of the competing technologies in the VOC concentration range up to $1 \%$. Catalytic oxidation is the most economical treatment technology for off-gases containing VOCs in the range 50 ppmv to $1 \%$, whereas carbon adsorption (off-site regeneration) is the most economical for VOC concentrations less than $50 \mathrm{ppmv}$. Because the VOC concentration in the vast majority of remediation off-gases is below $1 \%$, we conclude that the usefulness of membrane VOC-separation systems for remediation applications will be very limited.

\section{EXPERIMENTAL}

\subsection{Field Demonstration System Design: Vapor Separation System}

The design basis was a system to process $100 \mathrm{scfm}$ of remediation off-gas, producing the following three streams:

(1) Clean air: VOC concentration 10 ppmv or less.

(2) Clean water: VOC concentration 1 ppmw or less.

(3) Liquid VOC for disposal.

The goals for the VOC concentration in the air and water streams to be discharged reflect general targets and were not based on specific regulations. The exact discharge limits will vary from site to site depending on the particular VOCs present and local regulations.

The configuration shown in Figure 5 uses two membrane steps in series in the first membrane stage. Each step achieves a particular objective: the first step produces a stream concentrated in VOC to be fed to the VOC condensation section, and the second step produces a stream depleted in VOC 
to be vented. The two-step configuration allows for independent optimization of objectives (1) and (2), which substantially improves the efficiency of the system. ${ }^{13}$

\subsection{Field Demonstration System Design: Water Separation System}

A detailed flow diagram of the water separation system is shown in Figure 6 . The condensate from the first stage condenser is collected in a buffer volume \#1. The rising level triggers level switch $\# 1$ and valve \#1 discharges condensate for a short period of time into a loop which incorporates a buffer volume \#2 and a membrane contactor. The condensate is continuously recirculated from the buffer volume to the membrane contactor and back via a pump. The air side of the contactor is purged with atmospheric air or the air discharged from the second membrane step. The level in buffer volume \#2 will increase over time. Level switch \#2 causes valve \#2 to open, and about 1 gallon of water is discharged from the system. Assuming the remediation off-gas is saturated with water vapor, the frequency of the discharge from buffer volume \#2 will be about once per hour.

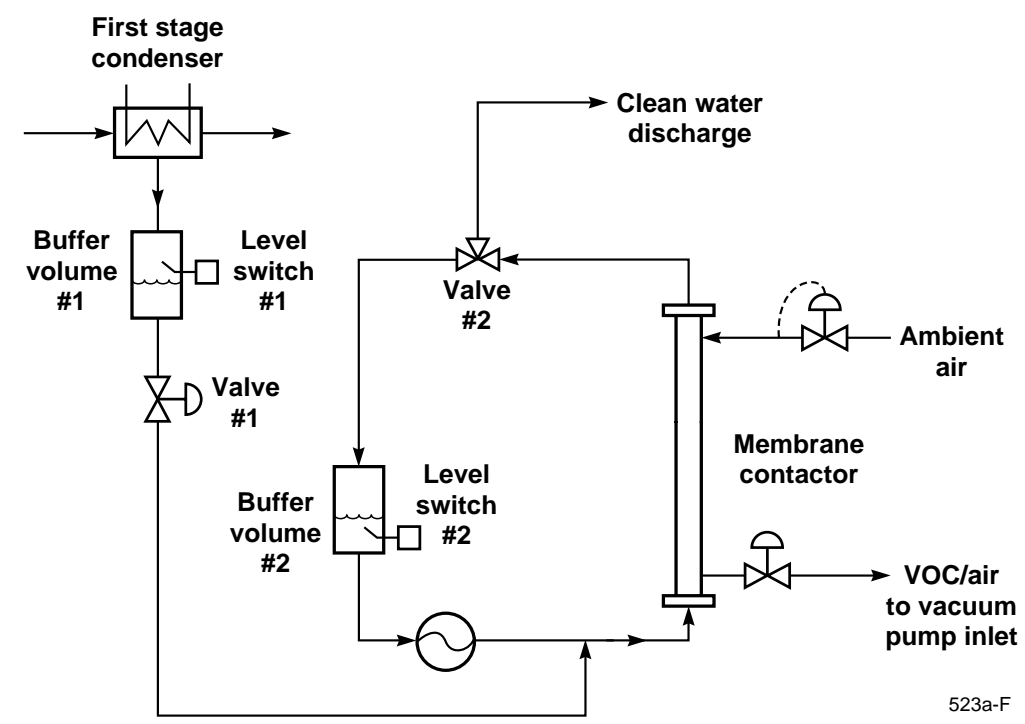

Figure 6. Schematic of the water separation system to remove VOCs from the condensate produced by the condenser in the first stage. 


\section{RESULTS AND DISCUSSION}

\subsection{Initial Testing at MTR}

The capacity of the 100 -scfm system made it impossible to operate the system at MTR with air containing meaningful amounts of VOCs. Therefore, we ran the system with ambient air as the feed gas and checked whether the flow rates, pressures and temperatures were in the expected ranges. One defective back-pressure regulator had to be replaced, but otherwise the system ran satisfactorily.

However, we were able to test the VOC removal efficiency of the water separation system at MTR. Buffer volume \#2 (see Figure 6) was filled with 10 gallons of water containing 6,000 ppmw methylene chloride. Water was recirculated through the membrane contactor at a rate of $2.7 \mathrm{gpm}$; the sweep air flow rate was $1 \mathrm{scfm}$. Figure 7 shows the observed decline in methylene chloride concentration over time. The removal kinetics are first order as expected ${ }^{13}$ and the methylene chloride concentration was reduced by four orders of magnitude in 140 minutes. This experiment showed that the water separation system was working properly and that VOC concentrations below 1 ppmw could be achieved without any difficulty.

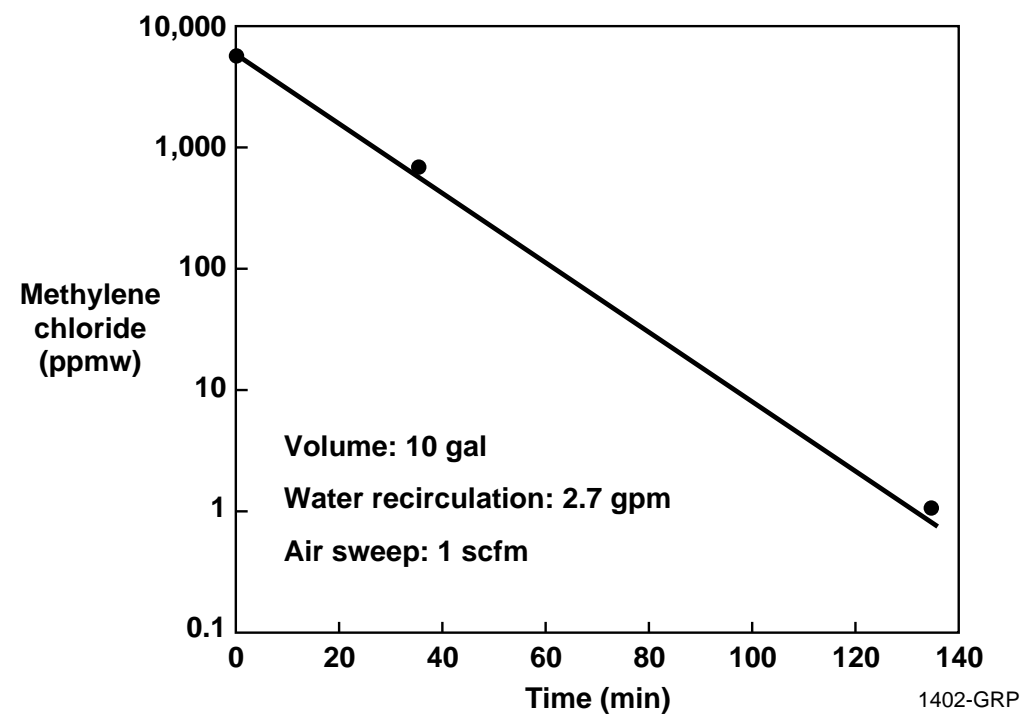

Figure 7. Methylene chloride concentration as a function of time in the buffer volume of the water separation system. The methylene chloride concentration is reduced by four orders of magnitude in 140 minutes.

\subsection{Test Site at McClellan Air Force Base}

The National Environmental Technology Test Site at the former McClellan Air Force Base runs remediation operations and provides an excellent infrastructure for testing novel technologies. The membrane system demonstration took place at Site $\mathrm{S}$ where a Soil Vacuum Extraction system is used to remove VOCs from contaminated soil. The SVE off-gas is treated in a catalytic oxidizer 
followed by a scrubber to remove hydrogen chloride and hydrogen fluoride formed by the oxidation of chlorinated and fluorinated VOCs. The membrane system was installed between the SVE unit and the catalytic oxidizer, as shown in Figure 8. This placement has the advantage that the performance of the membrane system does not affect VOC emissions. A photograph of the membrane system as installed at the test site is given in Figure 9.

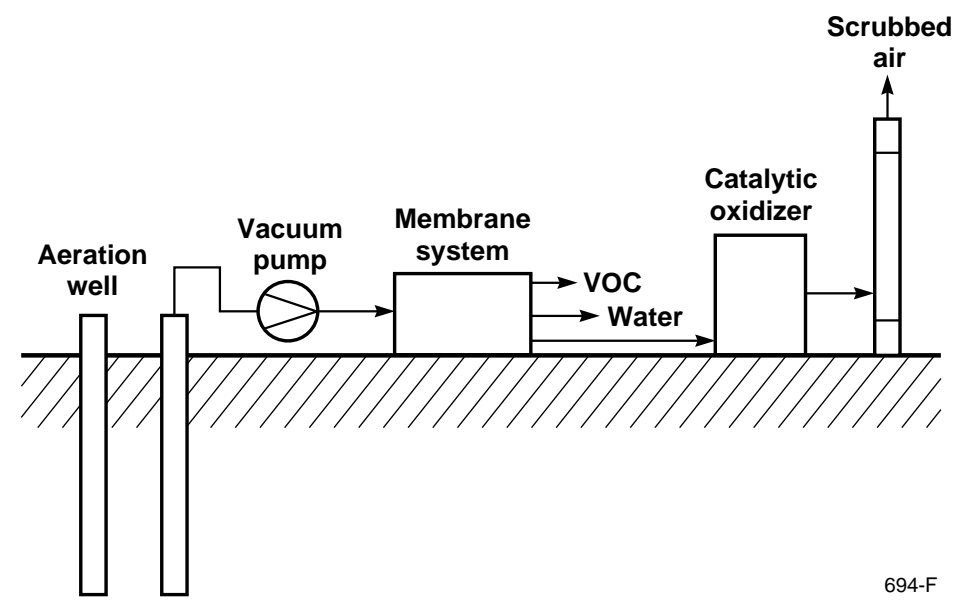

Figure 8. Diagram showing the connections between the SVE unit, the membrane demonstration system and the catalytic oxidizer at Site $\mathrm{S}$ at the National Environmental Technology Test Site, McClellan Air Force Base, Sacramento, CA. 


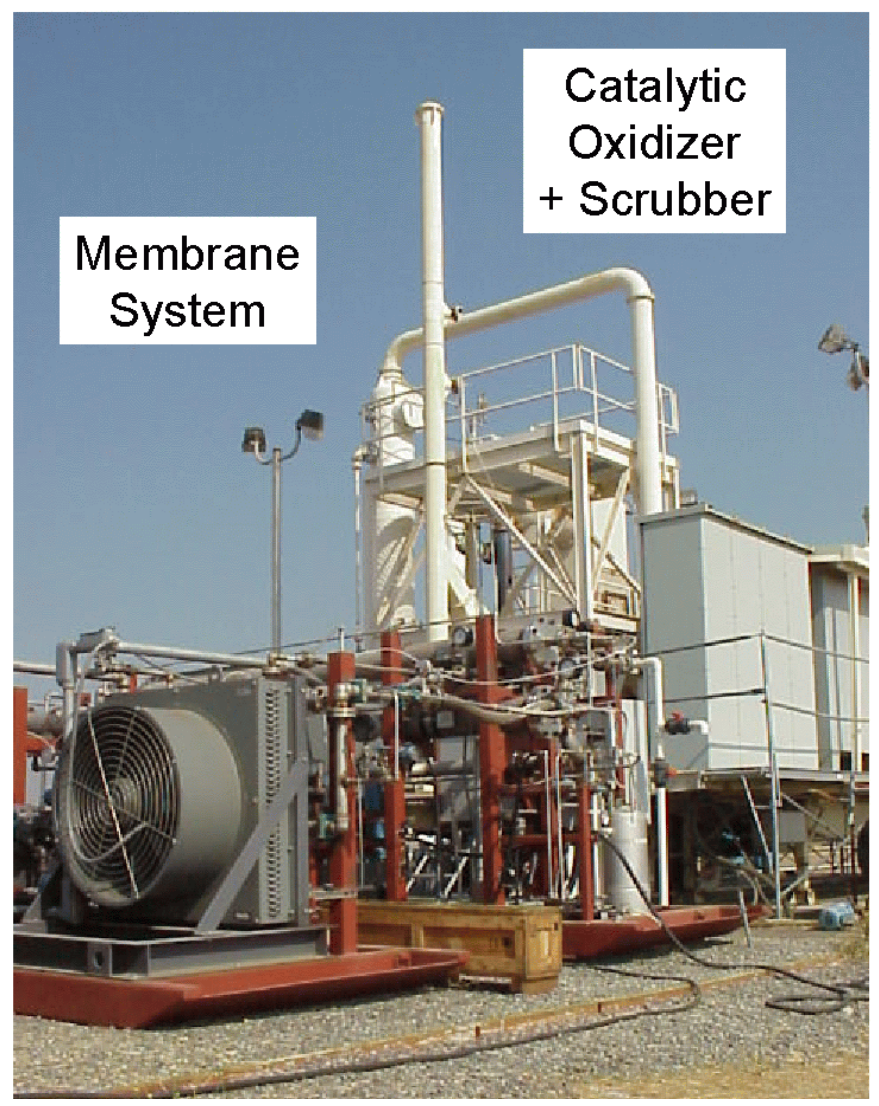

Figure 9. Photograph of membrane system installed at test site.

An example of the typical composition of the SVE off-gas is given in Table 2. The off-gas contains over twenty VOCs; the three typically present at the highest concentrations are 1,1,1-trichloroethane, trichloroethene and tetrachloroethene. The total VOC concentration on September 14, 1999 was $67,700 \mathrm{ppmv}$, and the range of total VOC concentration encountered during the 1999-2000 test period was 101,000 ppmv to 23,000 ppmv. 
Table 2. Composition of SVE Off-Gas on September 14, 1999, Determined by EPA Method 8021.

\begin{tabular}{||l|c||}
\hline \multicolumn{1}{|c|}{ VOC } & Concentration (ppbv) \\
\hline Dichlorodifluoromethane & 2,100 \\
\hline Chloromethane & ND \\
\hline Vinyl chloride & 1,500 \\
\hline Trichlorofluoromethane & 210 \\
\hline 1,1-Dichloroethene & 5,700 \\
\hline Methylene chloride & 340 \\
\hline trans 1,2-Dichloroethene & $\mathrm{ND}$ \\
\hline 1,1-Dichloroethane & 4,600 \\
\hline cis 1,2-dichloroethene & 7,700 \\
\hline Chloroform & 190 \\
\hline 1,1,1-Trichloroethane & 12,000 \\
\hline Carbon tetrachloride & $\mathrm{ND}$ \\
\hline 1,2-Dichloroethane & 230 \\
\hline Trichloroethene & 11,000 \\
\hline Toluene & 4,000 \\
\hline Tetrachloroethene & 13,000 \\
\hline Chlorobenzene & 310 \\
\hline Ethylbenzene & 940 \\
\hline$m+p-$ Xylenes & 3,800 \\
\hline o-Xylene & 2,000 \\
\hline Bromochloromethane & 122 \\
\hline 1,4-Dichlorobutane & 105 \\
\hline Naphthalene & $\mathrm{ND}$ \\
\hline & 69,800 \\
\hline
\end{tabular}




\subsection{Demonstration System Performance}

\subsubsection{Effect of Carbon Dioxide Content of SVE Off-Gas on System Performance}

The system was installed at Site S and connected between the SVE unit and the catalytic oxidizer. Initially, the system was operated with ambient air as the feed gas, handling $80 \mathrm{scfm}$ of air with the first stage operating at 190 psia pressure. On March 4, 1999 the system feed was switched to the SVE off-gas. After a few hours of operation the first-stage pressure had dropped to $150 \mathrm{psia}$ and the throughput to $35 \mathrm{scfm}$. On switching back to ambient air, the system returned to the operating conditions obtained previously. Based on this behavior we suspected that the SVE off-gas contains a highly permeable, but not very condensable component. Indeed, gas chromatography analysis performed at MTR revealed that the SVE off-gas contains 1 to 3\% carbon dioxide, which was not known to us and consequently had not been allowed for in the design calculations.

Figure 10 gives the carbon dioxide concentration determined by MTR during the testing period. Soil Vacuum Extraction operations aerate the soil as the stripping air moves through it. This results in aerobic biodegradation of the VOCs present in the soil to form carbon dioxide. Therefore, we suspect that the presence of carbon dioxide is common in SVE off-gases.

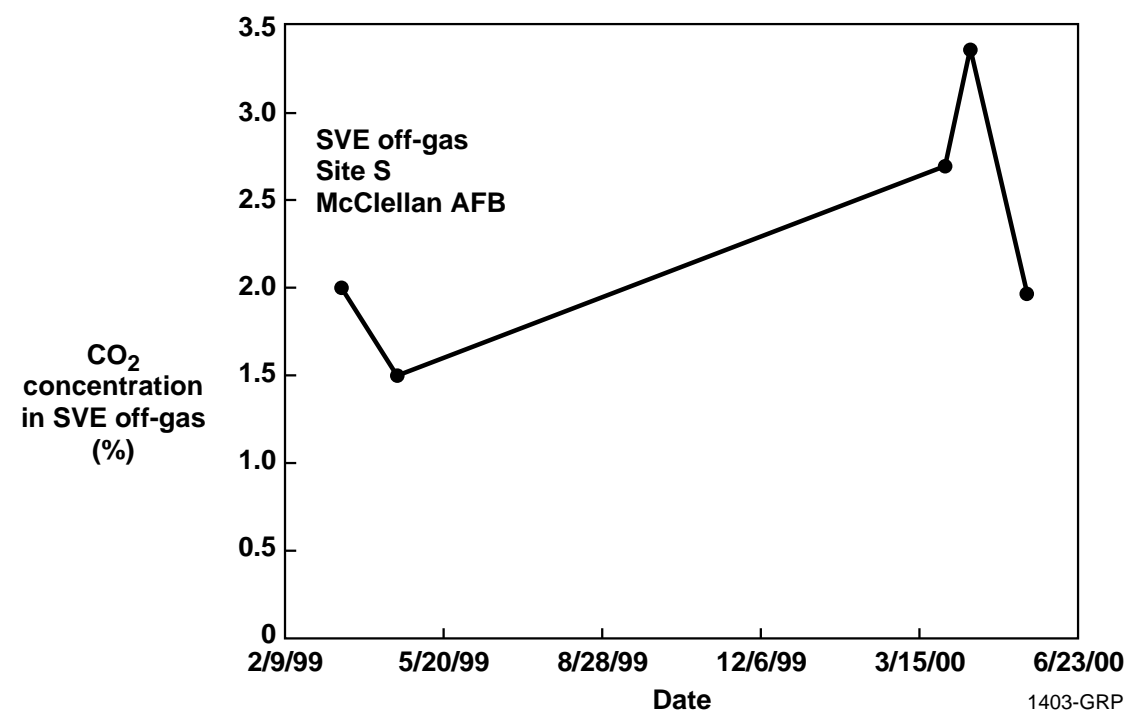

Figure 10. Carbon dioxide concentration in SVE off-gas at McClellan Air Force Base, Site S.

The membrane used in the system is very permeable to carbon dioxide. Consequently, the carbon dioxide is enriched in the recirculated permeate streams, and the flow rates of the recirculation streams increase significantly. Because the first-stage compressor compresses the feed stream and recompresses the recirculation streams, an increase in the flow rate of the recirculation streams will decrease the capacity available to handle the feed stream. Process simulations taking the presence of carbon dioxide into account confirm that a carbon dioxide concentration in the range 1 to $3 \%$ is sufficient to reduce the throughput capacity of the membrane system by a factor of two to four. Based on the observations in the field and the calculations performed at MTR, we reduced the 
membrane area in the second step from 80 to $60 \mathrm{~m}^{2}$ with the objective of reducing the amount of gas recirculated to the feed compressor. The system throughput achieved under these conditions was in the range 25 to $45 \mathrm{scfm}$ of SVE off-gas.

\subsubsection{Performance Data}

\subsubsection{Removal of VOC from Air}

Starting on April 20, 1999 the membrane system was operated with SVE off-gas as the inlet gas. Inlet and discharge air samples were taken periodically and analyzed for VOC content by a local analytical laboratory, JPB Corporation of Sacramento, CA, using EPA method 8021. Figure 11 shows the total VOC concentrations in the inlet and discharge streams measured during the first test period. The complete composition data are given in Appendix A. Figure 11 shows that the VOC discharge concentration increased over time and eventually exceeded the target. At the end of the first test period we noticed that the discharge stream carried water and oil with the air. After shutdown, the system pressure vessels were opened and the membrane modules were removed. Inspection revealed that the membrane modules as well as the system's piping contained a mixture of water and oil. The source of the oil was the second-stage liquid-ring pump. The system was inspected critically and modifications were made to the liquid-ring vacuum pump oil/gas separator to prevent oil contamination. The water found in the system was most likely a result of poor draining of the first-stage condenser and subsequent flooding of the downstream coalescing filter. Solving this problem would have required a substantial amount of work that could not be performed in the field. We were able to reduce the problem by opening the drain valve of the coalescing filter housing periodically. However, this required the presence of an operator, and the problem was not entirely eliminated.

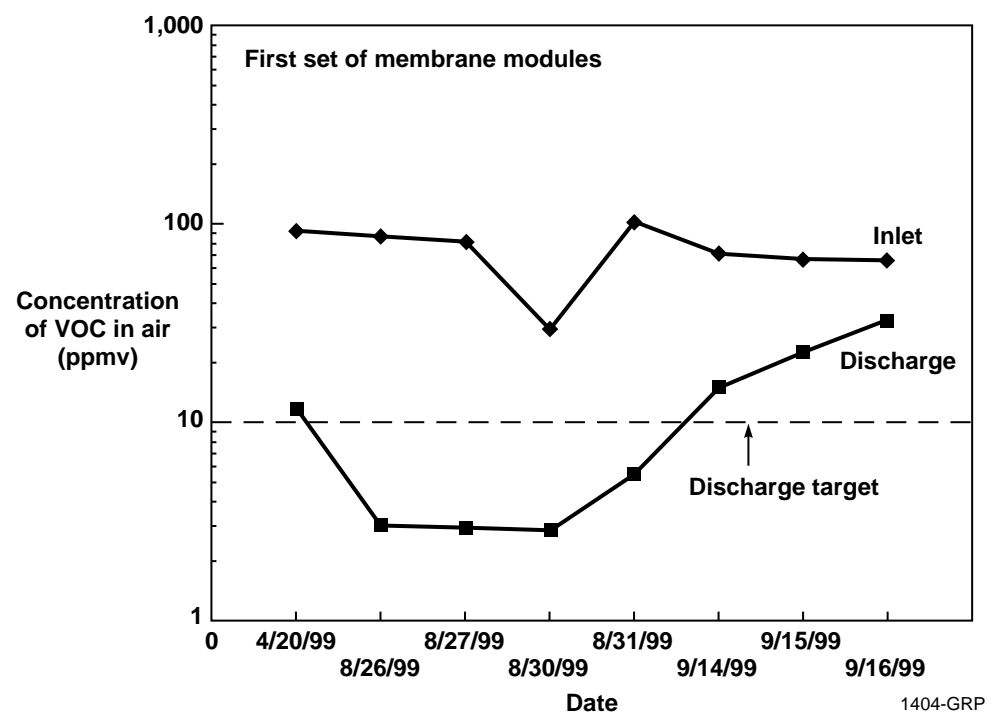

Figure 11. VOC concentration in the membrane system inlet air (the SVE off-gas) and in the system discharge stream. Results obtained with the first set of membrane modules. 
A replacement set of membrane modules was inserted into the system, which was then restarted on March 16, 2000. Figure 12 shows the total VOC concentrations in inlet and discharge observed during the second test period with the new modules. The complete composition data are given in Appendix B. As can be seen from Figure 12, the system performance was excellent initially, with VOC discharge concentrations one order of magnitude below the discharge target of 10 ppmv. However, just as in the first test period, the VOC discharge concentration increased steadily over time. After completion of the experiment, oil and water were again present in the system.

The conclusion we draw from these mixed results is that initially the system operates satisfactorily, but that fouling of the membrane modules with oil and water reduces performance within 2 weeks. The cause of the fouling is not entirely clear; MTR has operated similar systems without these problems. An example is the test performed at Hanford (see Figure 3) in which a system operated for 25 days without deterioration of performance.

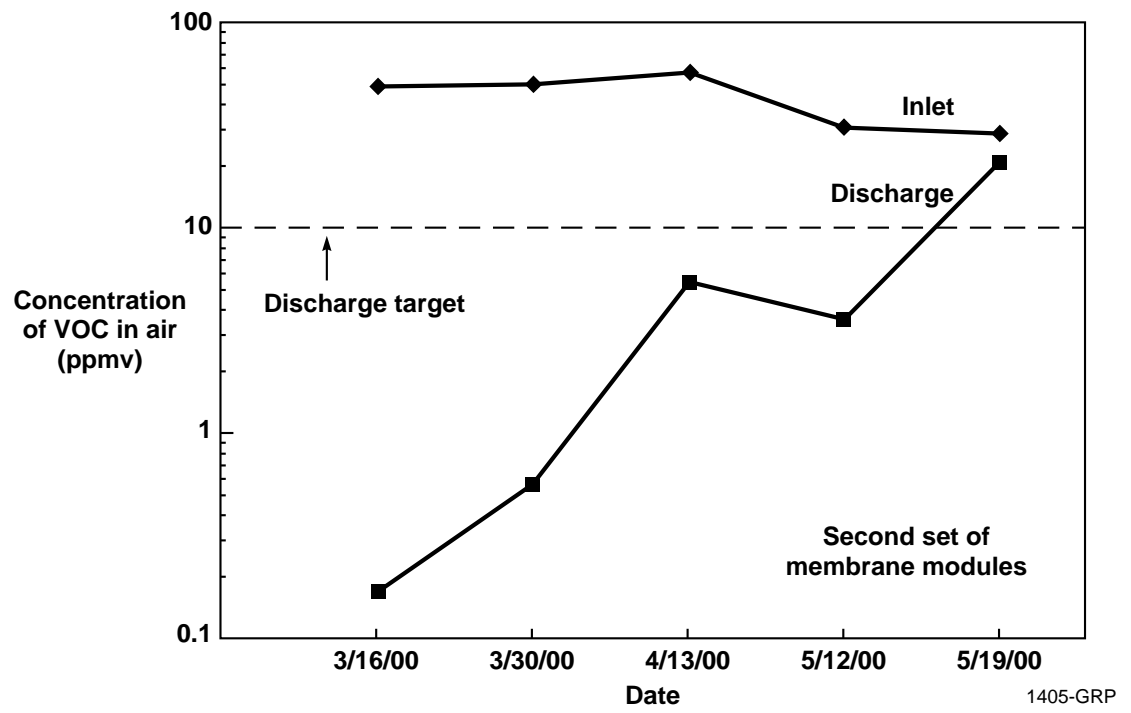

Figure 12. VOC concentration in the membrane system inlet air (the SVE off-gas) and in the system discharge stream. Results obtained with the second set of membrane modules.

\subsubsection{Removal of VOC from Water}

During the second test period, samples were collected from the first-stage condensate entering the water separation system and from the discharge stream produced by the water separation system. The samples were analyzed for their VOC content by the JPB Corporation using EPA method 8260. Figure 13 shows the total VOC concentrations for the inlet and discharge streams observed during the first test period. The complete composition data are given in Appendix C. The data in Figure 13 show that, with the exception of one data point, the water separation system met the discharge target of 1 ppmw or less. 


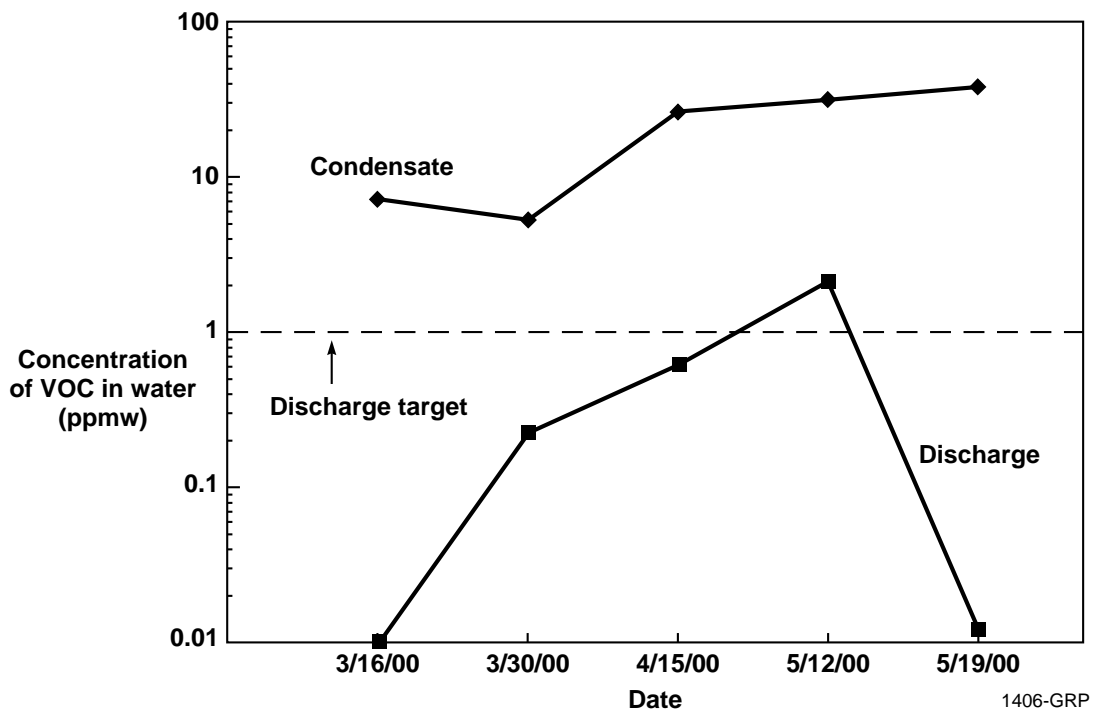

Figure 13. VOC concentration in the water separation system inlet water (the condensate from the first stage condenser) and in the water discharge stream.

\subsection{Economic Analysis}

The cost of remediating a 500-scfm SVE off-gas stream with a membrane system having the same configuration as the system tested at McClellan AFB was estimated. The presence of carbon dioxide in the off-gas was not taken into account, so this is a "best-case analysis" for the membrane system. The membrane system treatment costs were then compared with costs estimated for carbon adsorption and for catalytic oxidation followed by scrubbing. The conclusion from this analysis is that catalytic oxidation plus scrubbing is the preferred treatment option for most VOC-in-air remediation applications.

\subsubsection{Membrane System Cost Estimate}

The capital cost for the base-case membrane system, which treats $500 \mathrm{scfm}$ of air and reduces the VOC content from 5,000 to 10 ppmv, is shown in Table 3. This table lists the costs of the main components and includes the engineering and fabrication costs and manufacturer's margin. The total capital cost for a skid-mounted, turn-key system is estimated to be $\$ 660,000$. 
Table 3. Capital Cost Breakdown for Membrane System Treating $500 \mathrm{scfm}$ of Air Contaminated with 5,000 ppmv VOC. The air discharge stream produced contains 10 ppmv VOC.

\begin{tabular}{|lr|}
\hline Cost Component & Cost (\$) \\
Membrane modules & 70,000 \\
Module pressure vessels & 40,000 \\
Screw compressor & 40,000 \\
Liquid ring pump & 73,000 \\
Condenser/chiller & 27,000 \\
Water separation system & 10,000 \\
Programmable logic controller & 10,000 \\
Skid, piping, valving & 60,000 \\
System engineering, fabrication and manufacturer's margin & 330,000 \\
& TOTAL \\
\hline
\end{tabular}

Table 4 lists the processing costs for the 500 -scfm membrane system. The membrane replacement costs are based on a three-year membrane module life. This lifetime has been demonstrated for MTR membranes used in commercial systems in the chemical industry.

Table 4. Processing Cost Breakdown for Membrane System Treating $500 \mathrm{scfm}$ of Air Contaminated with 5,000 ppmv VOC. The vent air produced contains 10 ppmv VOC.

\begin{tabular}{||lr||}
\hline Cost Component & Cost $(\$)$ \\
Capital depreciation $(20 \% / \mathrm{yr})$ & 132,000 \\
Module replacement & 27,500 \\
Maintenance and Labor & 50,000 \\
Energy $(\$ 0.07 / \mathrm{kWh})$ & 250,000 \\
Waste disposal $(\$ 1.25 / \mathrm{kg})$ & 215,000 \\
TOTAL processing costs per year & 675,000 \\
TOTAL processing costs per month & $\mathbf{5 6 , 0 0 0}$ \\
\hline
\end{tabular}

Repeating the calculations given in Table 4, we estimated the processing costs of the membrane system for different VOC feed concentrations. In each case, the VOC concentration in the vent stream was maintained at $10 \mathrm{ppmv}$. The resulting cost data are given in Table 5, which shows that the processing costs decrease slightly with decreasing VOC concentration, mainly due to lower waste disposal costs. 
Table 5. Processing Costs as a Function of the VOC Concentration in the 500-scfm Air Stream. VOC concentration in the vent is 10 ppmv in all cases.

\begin{tabular}{||c|c|}
\hline $\begin{array}{c}\text { VOC Concentration in Feed } \\
(\mathrm{ppmv})\end{array}$ & Processing Costs (\$/month) \\
\hline 10,000 & 60,000 \\
5,000 & 56,000 \\
1,000 & 41,000 \\
100 & 35,000 \\
\hline
\end{tabular}

\subsubsection{Comparison with Competing Technologies}

In our Phase I Technical Report, ${ }^{13}$ carbon adsorption was the only competing technology considered. However, the technology currently in use at McClellan AFB for off-gas treatment is catalytic oxidation followed by scrubbing to remove hydrogen chloride and hydrogen fluoride. Therefore, we included catalytic oxidation as a competing technology in the comparative analysis presented here.

\subsubsection{Carbon Adsorption}

Two different types of carbon adsorption process are used, depending on the mass of VOC to be removed from the off-gas. If the VOC concentration is low, carbon canisters are used. These canisters are replaced when fully loaded, and the used canisters are shipped offsite for regeneration at a cost of approximately $\$ 2.50 / \mathrm{kg}$ of carbon. In the $0-200 \mathrm{ppm}$ VOC range, carbon will typically adsorb $5 \%$ of its weight of VOC; thus, offsite regeneration costs approximately $\$ 50 / \mathrm{kg}$ of VOC adsorbed.

If the VOC concentration is in the 200-1,000 ppm range, offsite regeneration becomes too expensive, and onsite regeneration is used. Fully automatic dual-bed regeneration systems are available for sale or as rental units. The monthly rental fee for a system treating a 500 -scfm air stream with a VOC concentration below 1,000 ppmv is approximately $\$ 20,000$. Regeneration with steam is the common practice, but the VOC removed is then contaminated with 20-30 volumes of condensed steam, so the volume of secondary waste produced is large. This presents a problem in remediation applications because the $\mathrm{VOC} /$ water mixture has to be shipped as hazardous waste at a cost of $\$ 1.25 / \mathrm{kg} .{ }^{14}$ For this reason, a system designed to regenerate the carbon with hot air under vacuum received significant attention in 1994 and $1995 .{ }^{15}$ The advantage of regeneration without steam is that significantly less water is recovered, which reduces the disposal costs. However, the system experienced serious corrosion problems, and the manufacturer is no longer in business. Therefore, for most applications, the carbon system competing with the membrane system will employ on-site steam regeneration. Use of carbon canisters with offsite regeneration is feasible only at very low VOC concentrations.

Monthly processing costs were calculated for the two carbon options as a function of the VOC content of the air stream to be treated. These costs are compared in Figure 14 with the monthly processing costs estimated for the membrane system and for catalytic oxidation. 


\subsubsection{Catalytic Oxidation}

Information on the costs associated with catalytic oxidation (including the scrubber) was provided by the McClellan AFB site and is based on actual operating cost data and on actual capital costs. Two quotes received by McClellan AFB show the capital cost for a complete catalytic oxidation system to be $\$ 350,000$ for a 800 -scfm capacity system and $\$ 250,000$ for a 400 -scfm system. ${ }^{16}$ On this basis, we estimated the capital cost for a 500 -scfm system to be $\$ 280,000$, which translates into a capital charge of $\$ 4,700$ per month at a capital depreciation rate of $20 \%$ per year.

The operating costs of the 800 -scfm catalytic oxidizer at McClellan are $\$ 12,000$ per month, of which $\$ 3,000$ per month is for natural gas. This cost scales with the air-flow-rate capacity. The other $\$ 9,000$ per month represents fixed costs that do not change with the flow-rate capacity of the oxidizer. Based on these numbers, we estimated the monthly operating costs for a 500 -scfm system to be $\$ 11,000$, which with the capital charge gives a processing cost of $\$ 15,700$ per month.

The processing costs of the catalytic oxidizer are essentially independent of the VOC concentration up to about 1,500 ppmv. At higher VOC concentrations the catalyst is in danger of melting, ${ }^{16}$ and diluent air must be added to control the temperature. For example, at a VOC concentration of 6,000 ppmv, the SVE off-gas would have to be diluted fourfold, and the required capacity increases from 500 to $2,000 \mathrm{scfm}$. This extra flow rate capacity increases the oxidizer processing costs, as shown by the data in Figure 14.

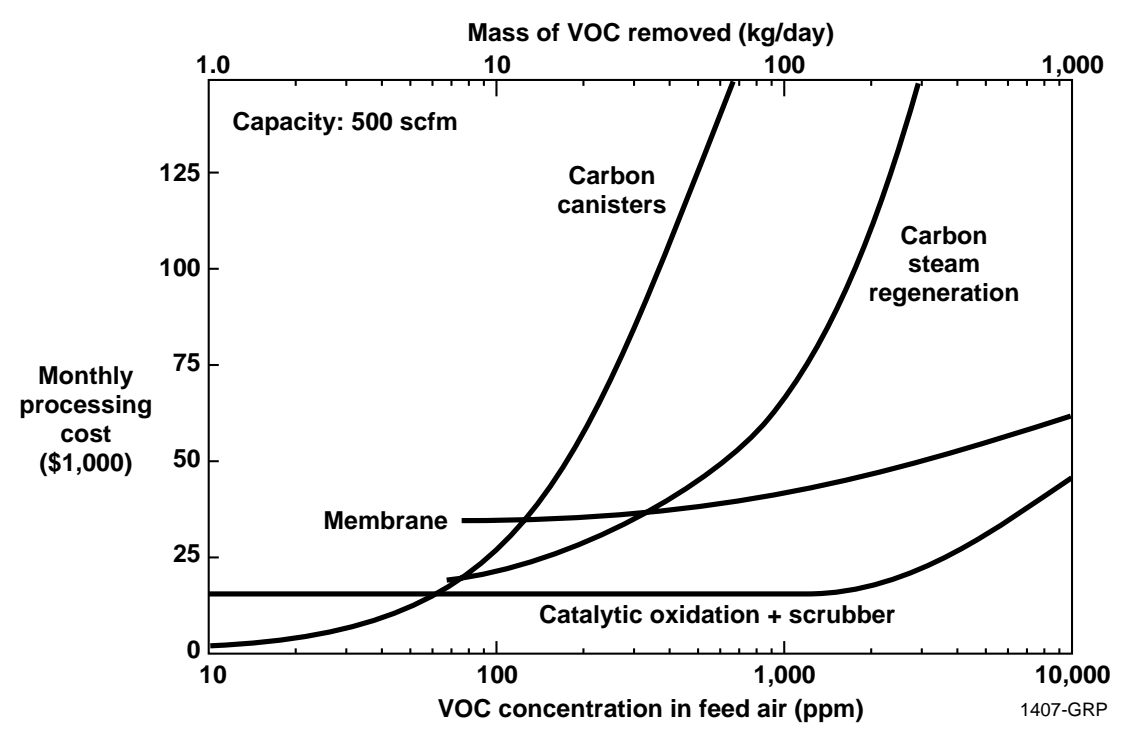

Figure 14. Processing costs as a function of VOC concentration in a 500 -scfm air stream for a membrane air-treatment process and for competing technologies. 


\section{CONCLUSION}

The McClellan AFB field test demonstrated that the membrane VOC-removal system can reduce VOC concentrations in air streams to below $10 \mathrm{ppmw}$ and water concentrations to below $1 \mathrm{ppmw}$. However, long-term demonstration of the performance was not achieved because the system suffered from two mechanical problems.

The conclusion from the economic analysis is that the processing costs of the membrane system are higher than those of the competing technologies for VOC concentrations up to $1 \%$. Catalytic oxidation followed by scrubbing is the most economical treatment technology for off-gases containing VOCs in the concentration range $50 \mathrm{ppmv}$ to $1 \%$, whereas carbon adsorption (off-site regeneration) is most economical for VOC concentrations less than 50 ppmv. Because VOC concentrations in the vast majority of remediation off-gases are below $1 \%$, we conclude that the usefulness of membrane VOC-separation systems in remediation applications will be very limited.

\section{REFERENCES}

1. G.J. van Amerongen, "Influence of Structure of Elastomers on their Permeability to Gases," J. Appl. Poly. Sci. 5, 307 (1950).

2. $\quad$ R.M. Barrer, "Permeability in Relation to Viscosity and Structure of Rubber," Trans. Far. Soc. $38,322(1942)$.

3. P. Meares, "The Diffusion of Gases through Polyvinyl Acetate," J. Am. Chem. Soc. 76, (1954).

4. V. Stannett, M. Szwarc, R.L. Bhargave, J.A. Meyer, A.W. Myers and C.E. Rogers, "Permeability of Plastic Films and Coated Paper to Gases and Vapors," Tappi Monograph Series, No. 23 (1962).

5. A.S. Michaels, W.R. Vieth and J.A. Barrie, "Diffusion of Gases in Polyethylene Terephthalate," J. Appl. Phys. 34, 13 (1963).

6. S.A. Stern and H.L. Frisch, "The Selective Permeation of Gases Through Polymers," Ann. Rev. Mater. Sci. 11, 523 (1981).

7. V.T. Stannett, W.J. Chewers, D.R. Paul, H.K. Lonsdale and R. W. Baker, "Recent Advances in Membrane Science and Technology," Adv. Poly. Sci. 32, 71 (1979).

8. S.L. Matson, J. Lopez and J.A. Quinn, "Separation of Gases with Synthetic Membranes," Chem. Eng. Sci. 38, 503 (1983).

9. S. Loeb and S. Sourirajan, "Sea Water Demineralization by Means of an Osmotic Membrane," ACS Advances in Chemistry Series 38, 117 (1963). 
10. L.T. Rozelle, J.E. Cadotte, K.E. Cobian and C.V. Kopp, "Nonpolysaccharide Membranes for Reverse Osmosis: NS-100 Membranes," in Reverse Osmosis and Synthetic Membranes, S. Sourirajan, Ed., National Research Council of Canada, Ottawa (1977).

11. C.V. King and J. Kaschemekat, "Volatile Organic Carbon/Air Separation Test Using Gas Membranes," Westinghouse Hanford Company Report to DOE Office of Technology and Development under contract DE-AC06-87RL10930, (August 1993).

12. FY 1993 Program Summary, U.S. Department of Energy Office of Environmental Restoration and Waste Management, Office of Technology Development, DOE/EM-0109P, (February 1994).

13. "Membrane System for Recovery of Volatile Organic Compounds from Remediation OffGases," April 1997, Phase I Topical Report submitted by MTR, Inc. to the DOE Federal Energy Technology Center under contract DE-AR21-96MC33081

14. Chemical Week (August 18, 1993).

15. "Purus A2000: A Significant Advance in VOC Removal Technology," Purus Company Brochure, (1994).

16. Personal communications, Mr. Timothy Chapman, Senior Environmental Engineer, National Environmental Technology Test Site, McClellan AFB.

\section{ACKNOWLEDGMENTS}

We gratefully acknowledge the support and advice provided by Mr. William J. Huber and Mr. Vijendra Kothari of the National Energy Technology Laboratory (Morgantown, WV), and by Mr. Timothy Chapman and Mr. David Renne of the McClellan Air Force Base National Environmental Technology Test Site (Sacramento, CA). 
APPENDIX A:

VOC Removal from Air, Data Obtained with First Set of Membrane Modules

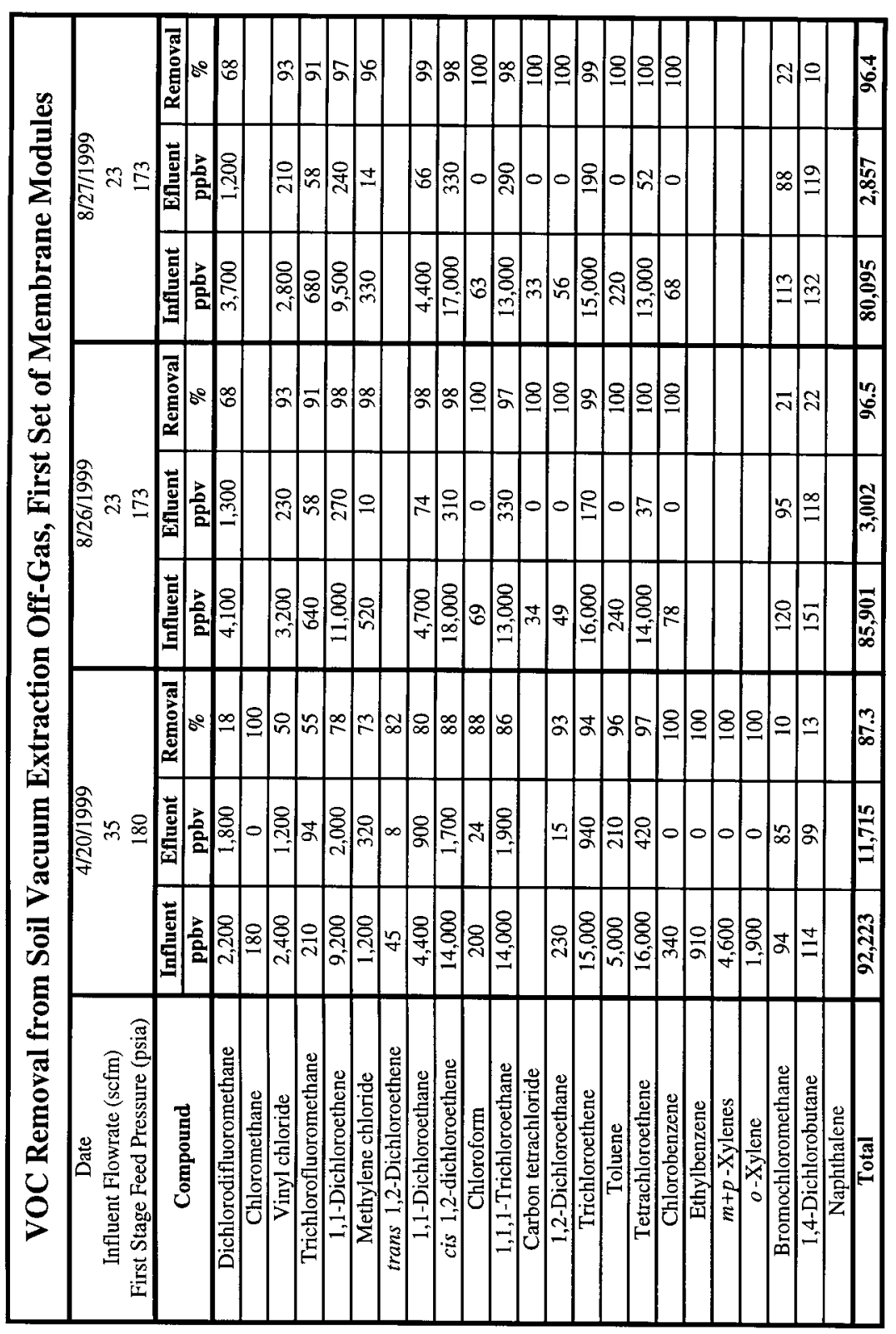




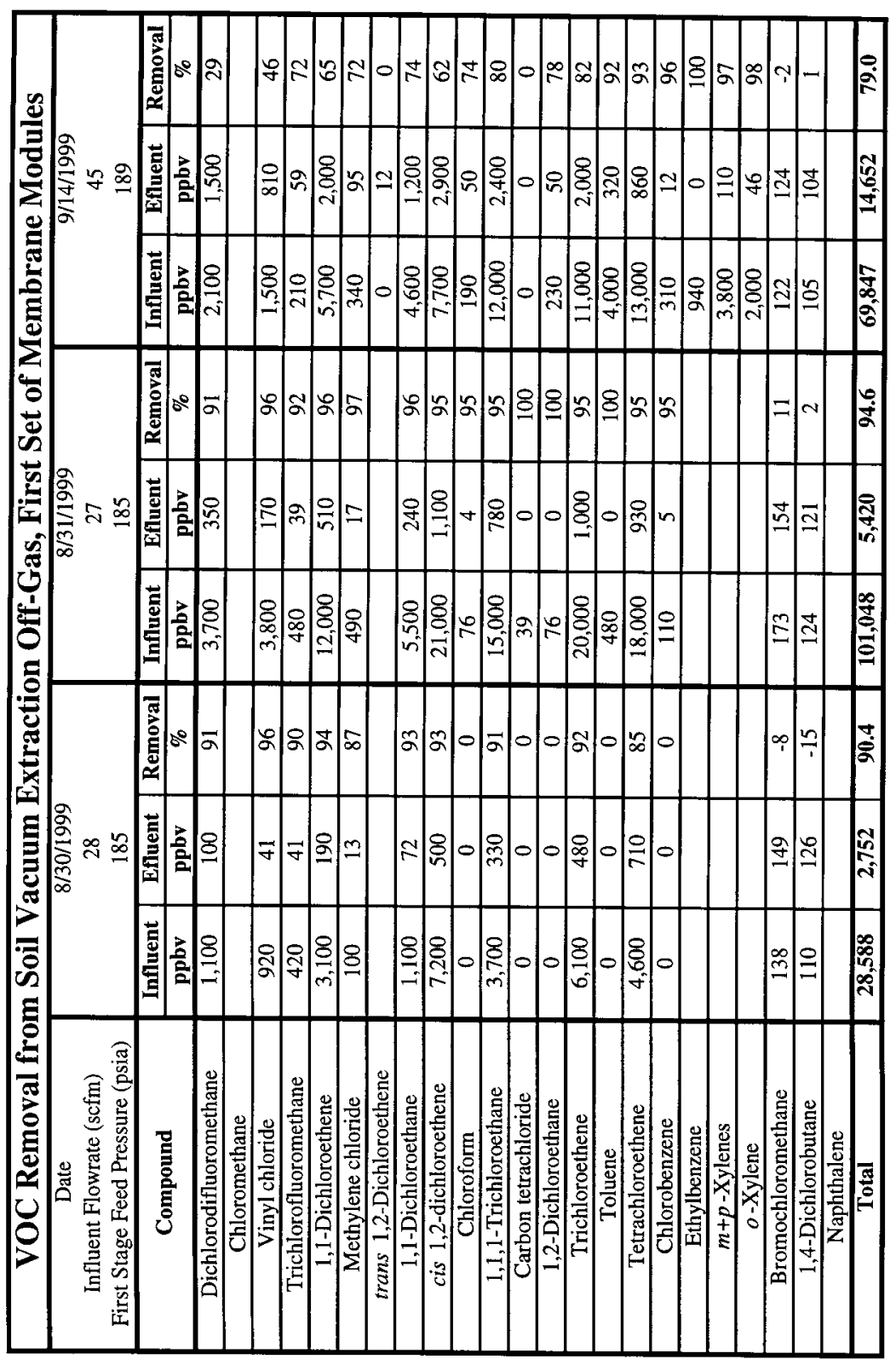

A-2 


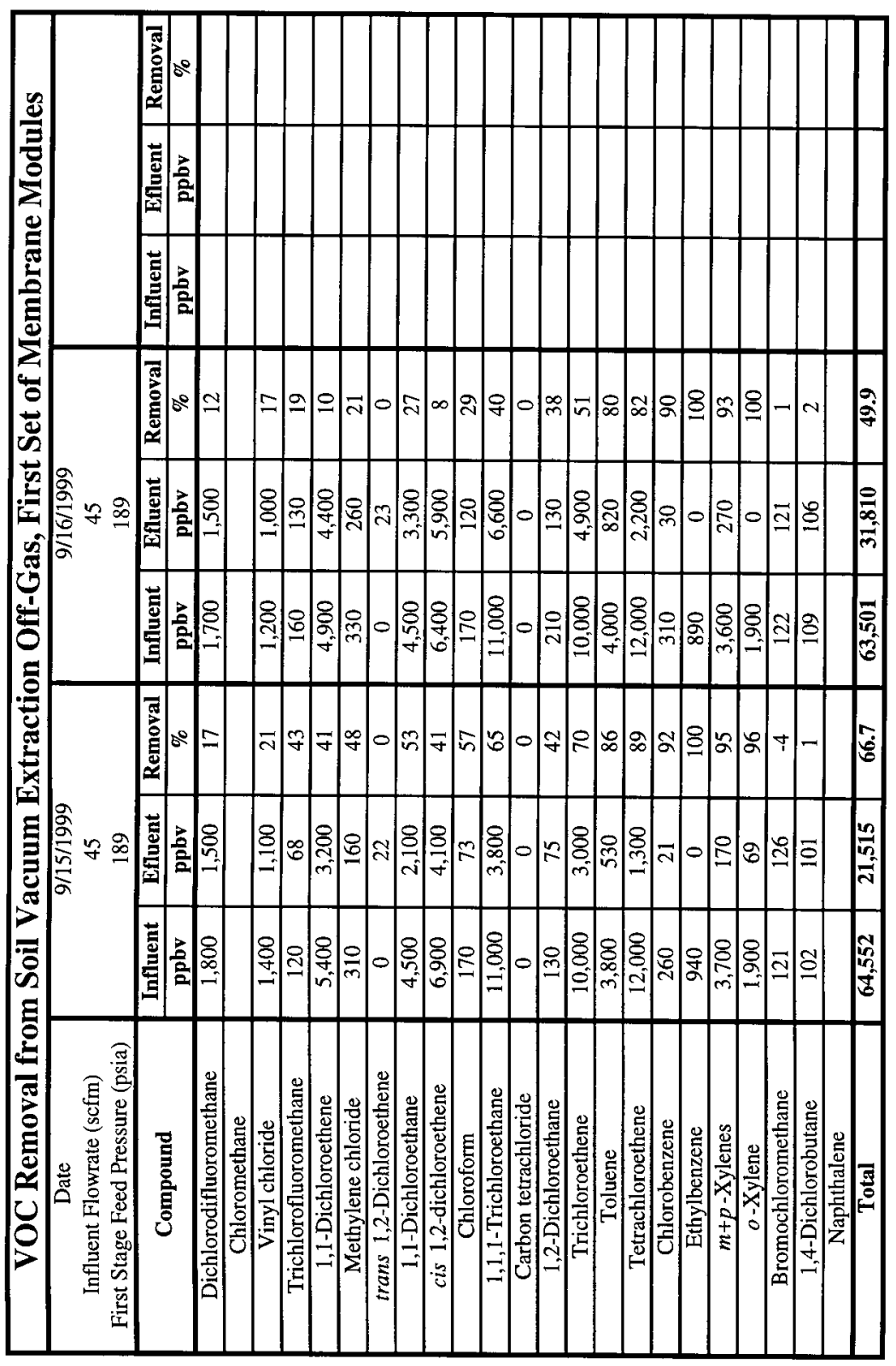

A-3 


\section{APPENDIX B:}

VOC Removal from Air, Data Obtained with Second Set of Membrane Modules

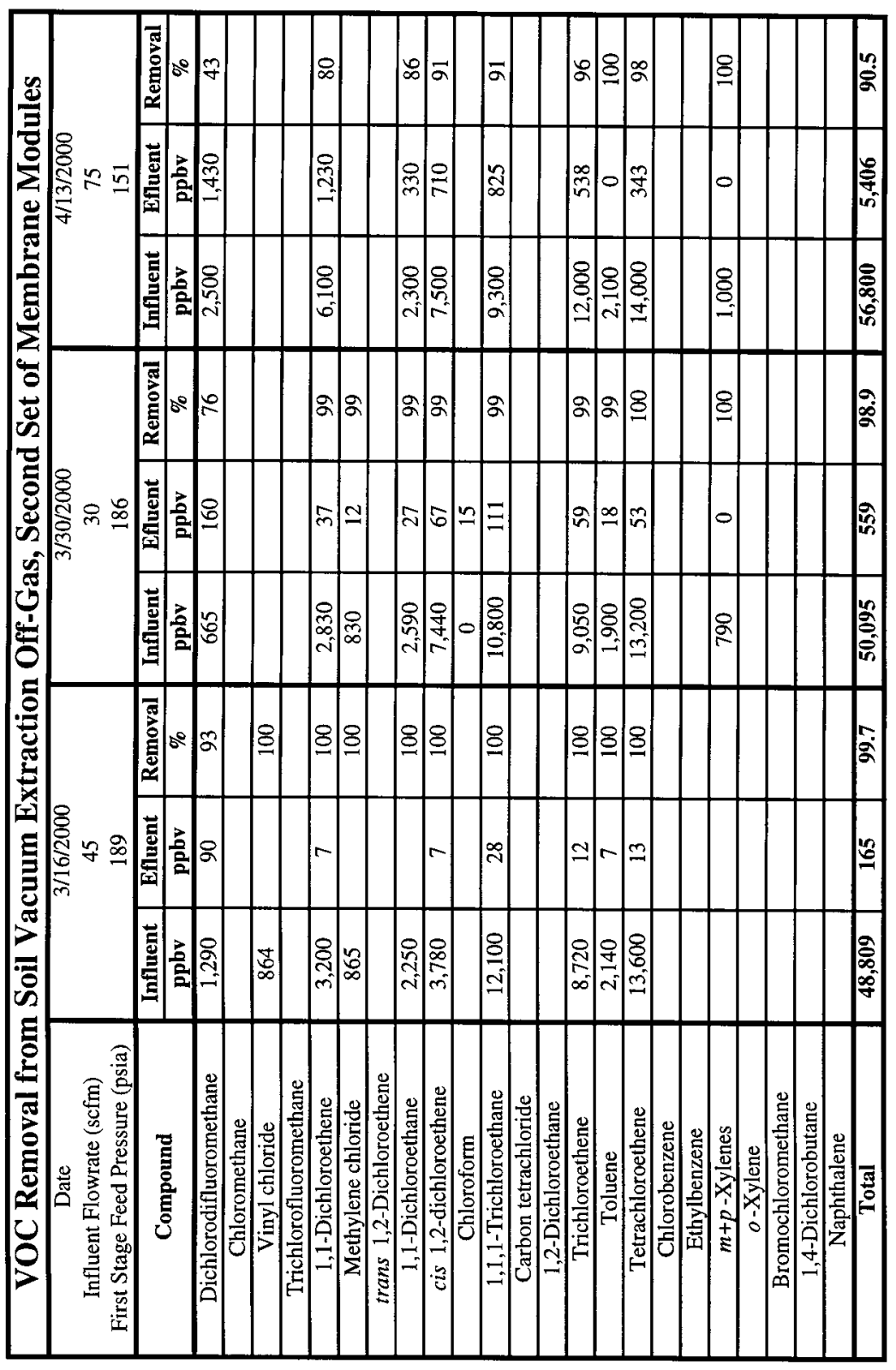




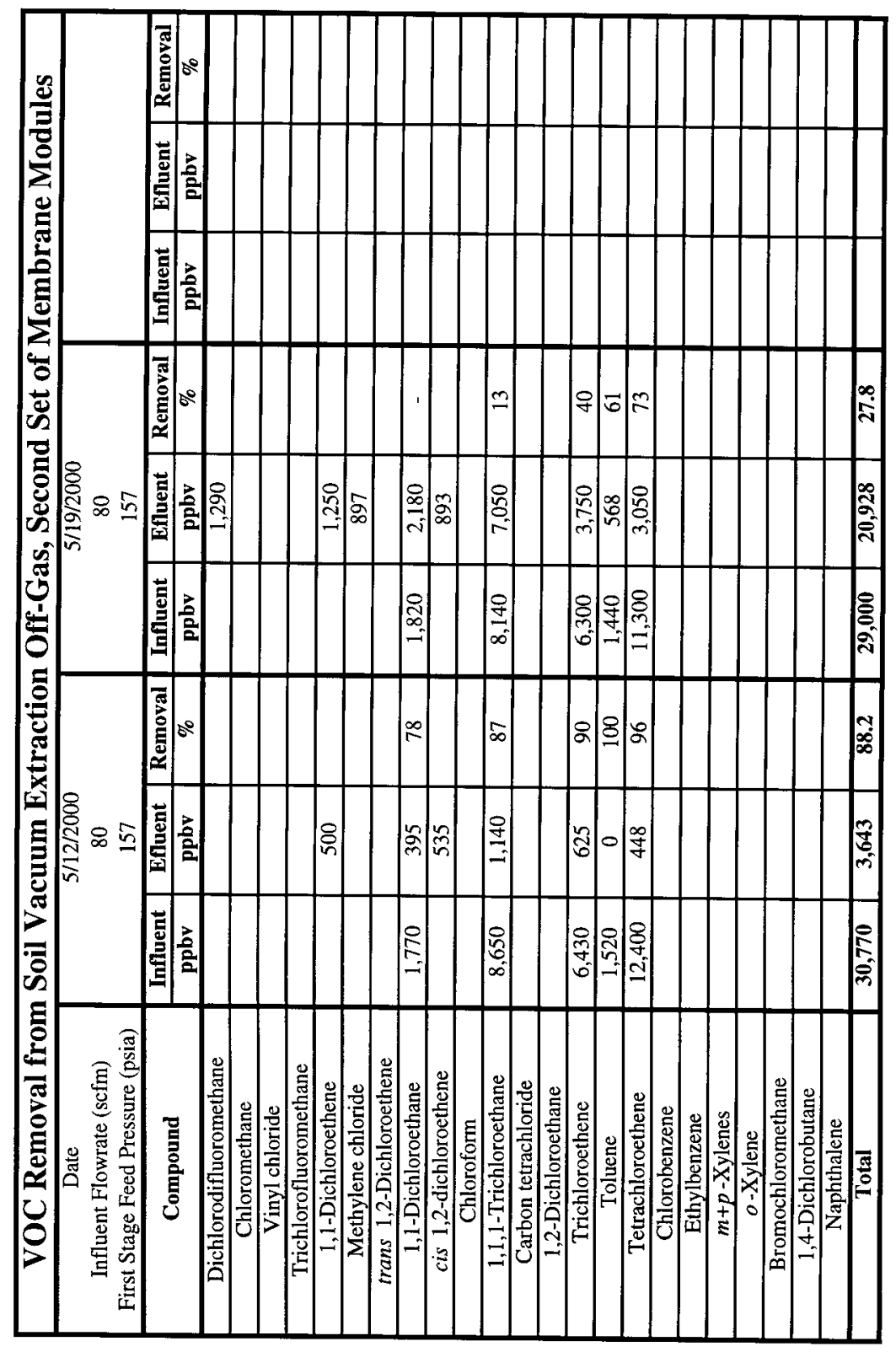

B-2 
APPENDIX C:

VOC Removal from Water, Data Obtained with Membrane Contactor

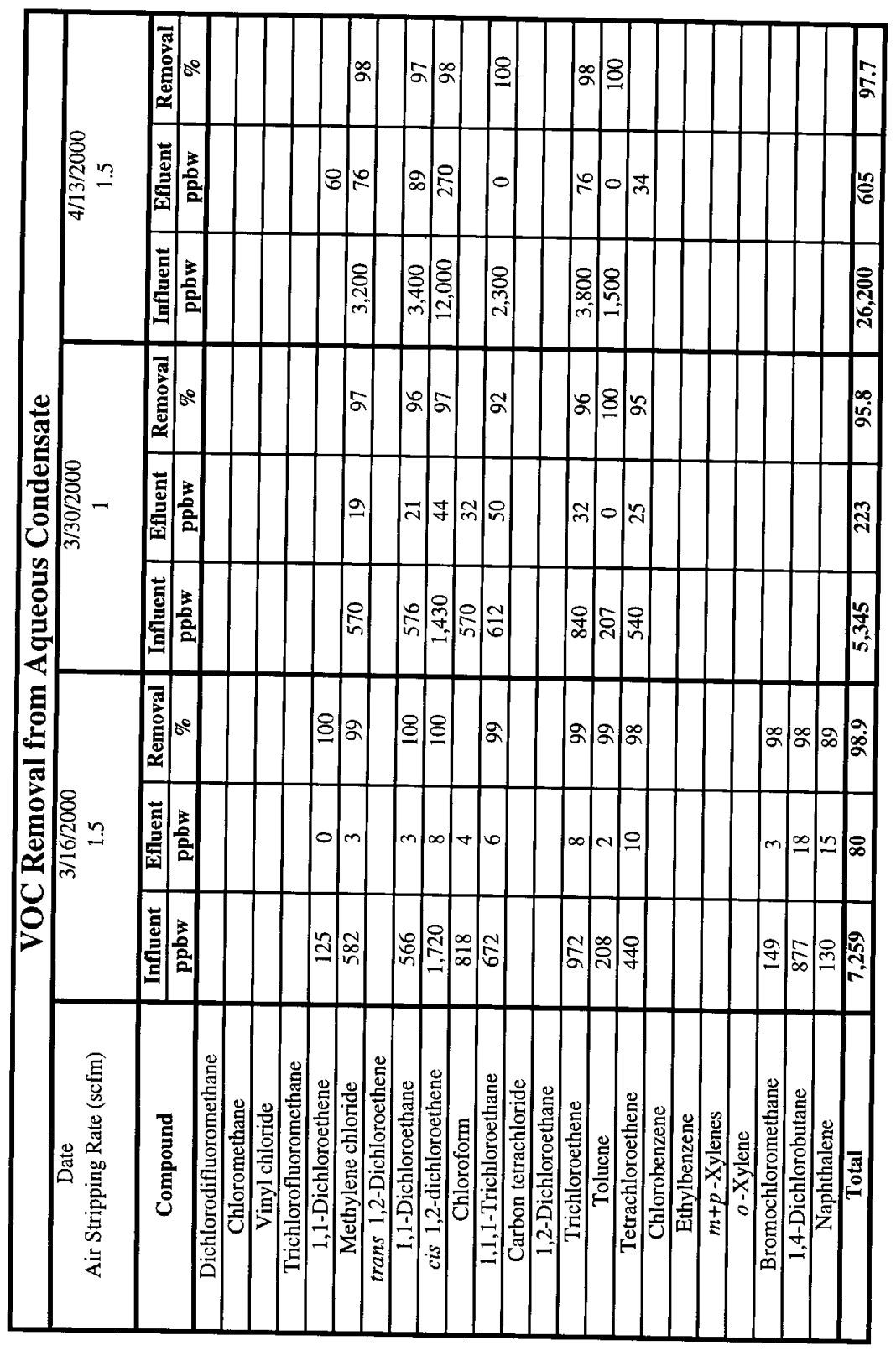




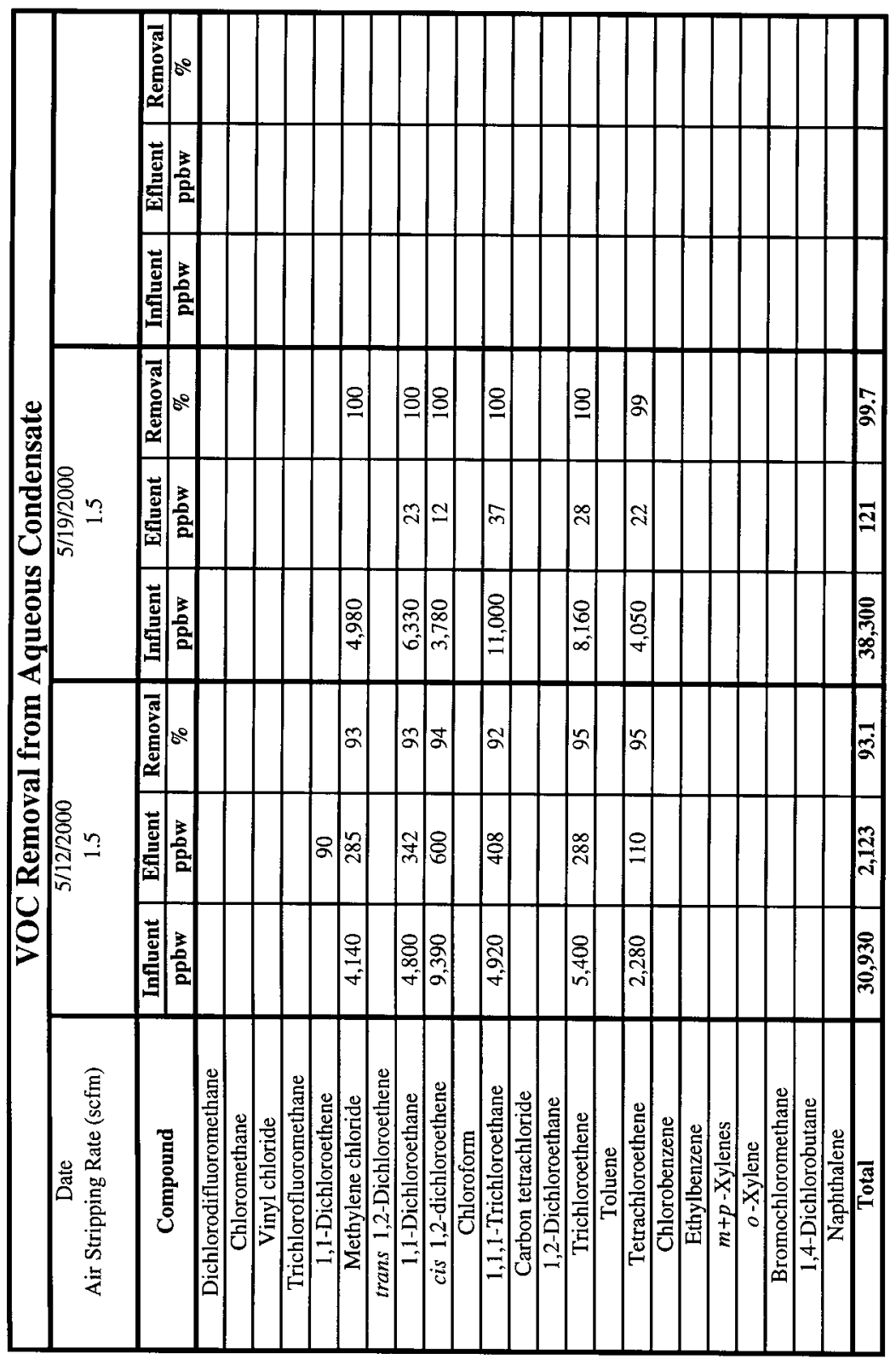

C-2 